\title{
Maximizing Land and Water Productivity by Intercropping Sunflower with Peanut under Sprinkler Irrigation
}

Amira A. El-Mehy ${ }^{1}$, Ahmed M. Taha ${ }^{2}$ and Ahmed M. M. Abd-Allah ${ }^{1}$

\begin{abstract}
Effective intercropping pattern, use of highly efficient irrigation system and proper irrigation scheduling are one of the current challenges in agriculture sector for saving water, maximizing crop production and economic benefits. Thus, a two-year field experiment was conducted at Ismailia Research Station (300 35' N latitude, 30o 26' E longitude, 20.0m above MSL), Egypt during the two growing seasons of 2016 and 2017 to study the effect of three irrigation treatments $(1.2,1.0$ and 0.8 ETo calculated by the BIS model) and five peanut/sunflower intercropping patterns $((P 1=100 \%$ peanut $+25 \%$ sunflower $),(P 2=100 \%$ peanut $+33 \%$ sunflower $),(P 3=$ $100 \%$ peanut $+50 \%$ sunflower $),(P 4=$ sole peanut $)$, and (P5 = sole sunflower)) on yield and its components of both crops, applied irrigation water, consumptive use, land and water productivity and net income. The experimental layout was designed in strip plot with three replicates. The results indicated that light intensity percentage significantly decreased with the 1.2 ETo treatment. The highest values of growth and yield of pod, seed and oil of peanut and sunflower were detected with the application of 1.2 ETo. Intercropping sunflower with peanut significantly reduced the yield of both crops in both seasons. However, intercropping sunflower at low density (P1) recorded the maximum values for yield and yield components of peanut, compared to the P2 and P3 treatments. The highest values of applied water (451 and $439 \mathrm{~mm})$ and consumptive use $(403$ and $415 \mathrm{~mm})$ were obtained in the first and second growing seasons, respectively when $\mathrm{P3}(\mathbf{1 0 0 \%} \mathrm{P}+\mathbf{5 0 \%} \mathrm{S})$ was irrigated with 1.2 of ETo. Intercropping sunflower with peanut increased water use efficiency $(\mathrm{kg} / \mathrm{mm}$ or cereal unit $/ \mathrm{mm})$ compared with sole crop. The average of water equivalent ratio was highest (1.255) produced with P3 under 1.0 ETo treatment, as average of both growing seasons. The maximum value of land equivalent ratio (1.569) and net income (L.E. 22589/ha) were recorded with $P 3$ intercropping pattern irrigated with 1.2 of ETo treatment, on average basis of both growing seasons. Sunflower was the dominant component for the all intercropping systems, while peanut was the dominated crop. Thus, we recommend the implementation of $\mathrm{P3}$ intercropping system, namely $100 \%$ peanut $+50 \%$ sunflower irrigated with 1.2 of ETo to increase land productivity in sandy soil under sprinkler irrigation or with 1.0 of ETo to save on the applied irrigation water, with yield lose were low. Under severe drought conditions, we recommended application of 0.8 ETo.
\end{abstract}

Keywords: Sprinkler irrigation, BIS model, Water productivity, Intercropping patterns, Peanut, Sunflower.

\section{INTRODUCTION}

The agricultural production and development of arid and semi-arid regions rely mainly on irrigation. Egypt depends on irrigated agriculture in more than $95 \%$ of its agricultural area (Abou Zeid, 2002). Egypt water policy mainly depends on the expansion of modern irrigation techniques in the newly reclaimed desert lands and improvement irrigation practices in the old lands of Delta and Valley. The application of modern irrigation techniques, such as drip, bubbler and sprinkler to increase irrigation efficiency is one of the measures utilized for competent use of water (NWRP, 2002).

The current challenge in agriculture is to produce more yields by utilizing less water, especially in regions with limited land and water resources (Fereres and Soriano, 2007 and Zhang et al., 2012). Efficient irrigation systems require the selection of an appropriate method for the crop growth, adequate monitoring of the irrigation system and of water delivery and appropriate application rates depending on the growth stage of the crop. Irrigation requirements differ depending on the locations, soil types and cultural practices (Bilalis et. al., 2009; Abd El-halim et. al.,2016).

Severe drought stress has direct impact on photosynthetically active radiation, yield and its components compared to the optimum irrigation condition. Maximum crop production requires complete capture of incident solar radiation and can only be achieved with supporting sufficient levels of water and nutrients (Loomis and Connor, 2002). Plants irrigated at low water depletion of the total available soil water produced greater leaf area than plants irrigated at high levels of water depletion and therefore had greater intercepted photosynthetically active radiation (Langeroodi et al., 2014; Adeboye et al., 2016). Water stress and shading contribute to reduce legume component yield under intercropping (Lesoing and Francis, 1999). Seed yield and seed yield components (pod number per $\mathrm{m}^{2}$, seed number per $\mathrm{m}^{2}$ and individual seed weight) were significant declined by water stress (Haro et al., 2008). Rowland et al. (2012) indicated

${ }^{1}$ Crops Intensification Research Department, Field Crops Research Institute,

Agricultural Research Center; Giza; Egypt,

${ }^{2}$ Water Requirement and Field Irrigation Department, Soils,

Water and Environment Research Institute, Agricultural Research Center; Giza; Egypt,

Received March 01, 2018, Accepted March 31, 2018 
that, yields of peanut were reduced by $26 \%$ and $10 \%$ in 2005 and 2006 season, respectively, in the lowest irrigation treatment (50\% applied irrigation) compared with full irrigation (100\% applied irrigation). Drought significantly changed total oil, linoleic and behenic fatty acids content, plant fresh weight, dry weight, pod yield per plant, number of seed per plant, number of pod per plant, 100 sun dried seed weight, and 100 sun dried pod weight (Asik and Yildiz, 2015). A significant reduction in growth characters, yield and its attributes of sunflower under deficit irrigation was recorded compared with full irrigation (Nezami et al., 2008; Gholinezhad et al., 2009; Langeroodi et al., 2014; ElDakrourry, 2015).

The proper intercropping pattern increase light use efficiency (Awal et al., 2006; Jiao et al., 2008), achieve water saving (Gaballah and Ouda, 2008; Zhang et al., 2012; Feng et al., 2016; Metwally et al., 2017), with the advantage of high and stable yield than sole crop. Yield is taken as primary consideration in the assessment of the potential of intercropping practices. Sunflower and finger millet as intercrop reduced the pod yield of peanut (Sankaran and Kuppuswamy, 1992). Kandel et al. (1996) showed that sunflower oil content was not influenced by intercropped legumes. Intercropping sunflower with peanut significantly reduced pod and seed yield of the two crops compared to sole pattern. Peanut/sunflower intercropping pattern at low density of sunflower gave the highest values of yield and yield components of peanut. However, raising sunflower plant density recorded the highest value of sunflower seed yield/fed and produced higher land equivalent ratio (LER) and net income compared to peanut as sole crop. Sunflower was the dominant component for the all intercropping systems, while peanut was the dominated crop (El-Sawy et al., 2006; Nassar et al., 2008; and Abd El-Zaher et al., 2009).

Similarly, intercropping sunflower at high population density with soybean achieved the highest seed and oil yields per ha of sunflower compared to low population and vice versa true for head diameter, 100- seed weight, and yield per plant (Abdel-Wahab and El Manzlawy, 2016).

Peanut (Arachis hypogaea L.) and Sunflower (Helianthus annus L.) are two of the most important summer oil in the world. Peanut seeds contain high oil (45\%), 26-28\% protein, $20 \%$ carbohydrates and $5 \%$ fiber (Fageria et al., 1997). Sunflower has high content of unsaturated fatty acids and lack of cholesterol (Casadebaig et al., 2008). Intercropping sunflower is a trail to introduce oil crops in peanut area to increase oil production (El-Sawy et al., 2006). This study was initiated to assess the effect of irrigation treatments under different peanut/sunflower intercropping patterns on yield and yield components of peanut and sunflower, land equivalent ratio, water use efficiency and net return.

\section{MATERIALS AND METHODS}

\section{Experimental site description:}

A field experiment was conducted at Ismailia Experimental Research station $\left(30^{\circ} 35^{\prime} \mathrm{N}\right.$ latitude, $30^{\circ}$ $26^{\prime}$ E longitude, $20.0 \mathrm{~m}$ above mean sea level), Ismailia Governorate, Egypt, during 2016 and 2017 summer growing seasons. The experimental site represents the newly reclaimed sandy soil of East of Nile Delta. The climate is cool in winter with a mean air temperature of about $13.0^{\circ} \mathrm{C}$. Summer is hot with no rain, and with mean air temperatures that varies from 28.0 to $30.55^{\circ} \mathrm{C}$ during June, July, and August, as well as mean wind speed of $2.93 \mathrm{~m} / \mathrm{hr}$ during the daytime for these months. Average monthly weather data at the experimental site during the growing seasons for the period from 2011 to 2015 are presented in (Table 1). These data were used to calculate monthly reference evapotranspiration (ETo) values in the experimental site according to the Basic Irrigation Scheduling model (BISm) as described by Snyder et al. (2004).

Samples from the upper $60 \mathrm{~cm}$ soil surface were collected at $15 \mathrm{~cm}$ interval to determine the main soil physical, chemical properties, and soil-moisture constants. The obtained values are presented in (Table 2). The available macronutrient values of $\mathrm{N}, \mathrm{P}$, and $\mathrm{K}$ were $16.50,5.20$, and $62.20 \mathrm{mg} \mathrm{kg}^{-1}$, respectively.

Table 1. Mean monthly values of solar radiation (Srad), maximum temperature (Tmax), minimum temperature (Tmin), wind speed (Ws), dew point (Td), and reference evapotranspiration (ETo) at the experimental site from 2011 to 2015

\begin{tabular}{lcccccc}
\hline Month & $\begin{array}{c}\text { Srad } \\
\left(\mathbf{M J ~ m}^{-\mathbf{2}} \mathbf{d a y}^{-\mathbf{1}}\right)\end{array}$ & $\begin{array}{c}\text { Tmax } \\
\left.\mathbf{(}^{\mathbf{0}} \mathbf{C}\right)\end{array}$ & $\begin{array}{c}\text { Tmin } \\
\left({ }^{\mathbf{0}} \mathbf{C}\right)\end{array}$ & $\begin{array}{c}\mathbf{W s} \\
\left(\mathbf{m ~ s}^{\mathbf{- 1}}\right)\end{array}$ & $\begin{array}{c}\text { Td } \\
\left({ }^{\mathbf{0}} \mathbf{C}\right)\end{array}$ & $\begin{array}{c}\text { ETo } \\
\left(\mathbf{m m}_{\mathbf{~ d a y}} \mathbf{- 1}^{\mathbf{1}}\right)\end{array}$ \\
\hline May & 27.73 & 33.50 & 17.84 & 3.06 & 20.53 & 6.48 \\
June & 28.05 & 36.31 & 20.19 & 3.08 & 21.91 & 7.15 \\
July & 28.89 & 38.03 & 21.90 & 2.89 & 22.92 & 7.29 \\
August & 25.10 & 38.14 & 22.95 & 2.79 & 22.25 & 6.67 \\
September & 23.03 & 34.84 & 21.17 & 2.82 & 20.47 & 5.25 \\
\hline
\end{tabular}


Table 2. Some physical and chemical properties of the soil at the experimental site

\begin{tabular}{|c|c|c|c|c|}
\hline \multirow{2}{*}{$\begin{array}{l}\text { Soil properties } \\
\text { Particle size distribution: }\end{array}$} & \multicolumn{4}{|c|}{ Soil depth $(\mathrm{cm})$} \\
\hline & $0-15$ & $15-30$ & $30-45$ & $45-60$ \\
\hline Coarse sand, $\%$ & 68.55 & 73.55 & 74.10 & 77.15 \\
\hline Fine sand, $\%$ & 25.78 & 22.15 & 22.20 & 18.95 \\
\hline Silt, \% & 3.67 & 2.90 & 2.80 & 3.10 \\
\hline Clay, $\%$ & 2.00 & 1.40 & 0.90 & 0.80 \\
\hline Texture class & Sandy & sandy & sandy & sandy \\
\hline Bulk density, $\mathrm{Mg} \mathrm{m}^{-3}$ & 1.64 & 1.76 & 1.74 & 1.70 \\
\hline Field capacity, $\%$ w/w & 12.70 & 11.15 & 6.90 & 7.85 \\
\hline Permanent wilting point, $\% \mathrm{w} / \mathrm{w}$ & 3.65 & 2.90 & 2.15 & 2.10 \\
\hline Available water, $\%$ & 9.05 & 8.25 & 4.75 & 5.75 \\
\hline $\mathrm{pH}(1: 2.5)$ & 7.64 & 7.58 & 7.60 & 7.41 \\
\hline ECe, soil past extract, $\mathrm{dS}^{-1}$ & 0.56 & 0.54 & 0.50 & 0.48 \\
\hline \multicolumn{5}{|l|}{ Soluble cations, meq $\mathrm{L}^{-1}$} \\
\hline $\mathrm{Ca}^{2+}$ & 1.24 & 1.20 & 1.24 & 1.26 \\
\hline $\mathrm{Mg}^{2+}$ & 0.55 & 0.53 & 0.50 & 0.48 \\
\hline $\mathrm{Na}^{+}$ & 1.55 & 1.57 & 1.60 & 1.62 \\
\hline $\mathrm{K}^{+}$ & 0.16 & 0.18 & 0.14 & 0.16 \\
\hline \multicolumn{5}{|l|}{ Soluble anions, meq $\mathrm{L}^{-1}$} \\
\hline $\mathrm{CO}_{3}{ }^{2-}$ & - & - & - & - \\
\hline $\mathrm{HCO}_{3}^{-}$ & 1.05 & 1.15 & 1.06 & 1.08 \\
\hline $\mathrm{Cl}^{-}$ & 1.72 & 1.74 & 1.73 & 1.75 \\
\hline $\mathrm{SO}_{4}{ }^{2-}$ & 0.66 & 0.68 & 0.68 & 0.70 \\
\hline
\end{tabular}

Accordingly, the soil was characterized by low fertility and insufficient available water for plant growth. The electrical conductivity (EC) of irrigation water was $0.52 \mathrm{dS} \mathrm{m} \mathrm{m}^{-1}$, and $\mathrm{pH}$ value was 7.55 . Chemical and physical soil analyses were conducted by the standard methods as described by Tan (1996).

\section{Experimental design and tested treatments.}

A strip plot design with three replicates was used to conduct the field experiment. The horizontal plots (main plot) were devoted to the irrigation treatments (plot size was $576 \mathrm{~m}^{2}$ ). The vertical plots (sub-plot) were assigned to the intercropping pattern treatments. Intercropping plot size was $38.4 \mathrm{~m}^{2}$ ( 8 ridges $\left.\times 0.60 \mathrm{~m} \times 8 \mathrm{~m}\right)$. The tested treatments were as follows:

\section{Irrigation treatments (I).}

$\mathrm{I}_{1}$ : Irrigation with amounts of water equal to 1.2 ETo.

$\mathrm{I}_{2}$ : Irrigation with amounts of water equal to 1.0 ETo.

$\mathrm{I}_{3}$ : Irrigation with amounts of water equal to 0.8 ETo.

\section{Intercropping pattern treatments $(\mathbf{P})$}

$\mathrm{P}_{1}: 100 \%$ peanut $+25 \%$ sunflower (one row of peanut intercropped with sunflower at $20 \mathrm{~cm}$ apart alternated with three row of peanut left free).

$\mathrm{P}_{2}: 100 \%$ peanut $+33 \%$ sunflower (two row of peanut intercropped with sunflower at $30 \mathrm{~cm}$ apart alternated with two row of peanut left free).
$\mathrm{P}_{3}: 100 \%$ peanut $+50 \%$ sunflower (one row of peanut intercropped with sunflower at $20 \mathrm{~cm}$ apart alternated with one row of peanut left free).

$\mathrm{P}_{4}: 100 \%$ peanut (sole peanut, $\mathrm{P}$ ).

$\mathrm{P}_{5}: 100 \%$ sunflower (sole sunflower, $\mathrm{S}$ ).

\section{Cultural practices.}

Peanut (Giza 6 var.) and sunflower (Sakha 53 var.) seeds were cultivated on the $8^{\text {th }}$ and $23^{\text {rd }}$ of May 2016 and 2017. Sunflower crop was harvested on the $10^{\text {th }}$ of August of both 2016 and 2017 seasons. Furthermore, peanut crop was harvested on the $24^{\text {th }}$ of September of both 2016 and 2017 seasons. In all intercropping patterns and sole planting, peanut and sunflower were planting on ridges $60 \mathrm{~cm}$ apart, plants were thinned to one plant/hill. Nitrogen fertilizer (ammonium nitrate, $33.5 \% \mathrm{~N}$ ) was added at the rate of $142.8 \mathrm{~kg} \mathrm{~N} / \mathrm{ha}$, potassium sulfate was added at the rate of $119 \mathrm{~kg}$ $\mathrm{K}_{2} \mathrm{O} / \mathrm{ha}$, and $122 \mathrm{~kg} \mathrm{P}_{2} \mathrm{O}_{5} /$ ha of phosphoric acid $(60 \%)$ were added.

Peanut and sunflower crops were cultivated under a sprinkler system in a total area (horizontal plot) of 576 $\mathrm{m}^{2}(48 \times 12 \mathrm{~m})$ and an irrigation interval of three days. A solid-set sprinkler irrigation system with rotary RC 160 sprinklers of 0.94 to $1.30 \mathrm{~m}^{3} / \mathrm{hr}$ discharge rate at 2.80 bars nozzle pressure was used to irrigate the crops. The sprinkler system consists of main PVC pipe line (160 mm diameter), sub main PVC pipe lines $(110 \mathrm{~mm}$ diameter), and PVC lateral lines (50 $\mathrm{mm}$ diameter). The 
laterals were spaced at 12 X 12 meters apart. Application of the irrigation water treatments started from the fifth irrigation. All fertilizers were added through irrigation water (fertigation) using the differential pressure tank. Fertigation was done in $80 \%$ of irrigation time. Fertilizer doses were applied through after 11,21 , and 42 days from planting peanut and sunflower.

\section{Plant measurements.}

At 60 days from planting: Light intensity at the middle and bottom of the plant on five plants from each sub-plots of peanut and sunflower were measured by lux meter apparatus at mid-day and expressed as percentage from light intensity (100\%) measured above the plants according to Pearce et al. (1996).

At harvest: Ten guarded plants were taken randomly from the middle of each sub-plot to measure growth characters and yield components, while yield of both crops were estimated from each sub-plot and then converted to yield/ha.

Peanut traits: plant height, number and weight of pods/plant, seed weight/plant, 100-pod weight, 100seed weight, pod and oil yields/ha and oil \%.

Sunflower traits: plant height, number of leaves/plant, head diameter and weight, weight of seeds/plant, 100-seed weight, seed and oil yields/ha and oil $\%$.

To determine oil percentage $(\%)$ : Dried mature of seeds were grounded into very fine powder and oil\% was determined using Soxhelt apparatus and Hexane ether according to A.O.A.C. (1995).

\section{Irrigation-water measurements and crop-water} relations.

\section{Distribution uniformity (DU).}

The water distribution uniformity (DU) of the sprinkler system was measured in the field. The DU values were calculated by the equation developed by Merrim and Keller (1978) as follows:

$$
\mathrm{DU}=(\mathrm{Diq} / \mathrm{D}) \times 100
$$

where:

DU $=$ distribution uniformity $(\%)$.

Diq $=$ average depth of water collected by cans from sprinklers at the low quarter of the field $(\mathrm{cm})$.

$\mathrm{D}=$ average depth of water collected by cans from all sprinklers $(\mathrm{cm})$.

\section{Water consumptive use (WCU).}

Crop water use was estimated by the method of soil moisture depletion according to Majumdar (2002) as follows:

$$
W C U=\sum_{i=1}^{i-4} \frac{\theta 2-\theta 1}{100} \times B d \times d
$$

where:

WCU = water consumptive use or actual evapotranspiration, ETa $(\mathrm{mm})$.

$\mathrm{i}=$ number of soil layer.

$\theta 2=$ soil moisture content after irrigation, $(\%$, by mass).

$\theta 1=$ soil moisture content just before irrigation, $(\%$, by mass).

$\mathrm{Bd}=$ soil bulk density, $\left(\mathrm{g} / \mathrm{cm}^{3}\right)$

$\mathrm{d} \quad=$ depth of soil layer, $(\mathrm{mm})$.

Applied irrigation water:

The amounts of applied irrigation water were calculated according to the equation given by Vermeiren and Jopling (1984) as follows:

$$
A I W=\frac{E T o \times 1}{E a(1-L R)}
$$

where:

AIW $=$ depth of applied irrigation water $(\mathrm{mm})$

ETo $=$ reference evapotranspiration $\left(\mathrm{mm} \mathrm{d}^{-1}\right)$. ETo values calculated using BISm.

I = irrigation intervals (days)

$\mathrm{Ea}=$ irrigation application efficiency of the sprinkler irrigation system ( $\mathrm{Ea}=78 \%$ first seasons and $80 \%$ second season for sprinkler system).

LR = leaching requirements (was not considered in this experiment due to its indirect effect on the amount of water applied for water stress treatment, 0.8 ETo)

\section{Water equivalent ratio (WER):}

The WER quantifies the amount of water that would be needed in single crops to achieve the same yield as produced with one unit of water in intercrop and it is calculated according the formula of (Mao et al., 2012):

$\mathrm{WER}=\mathrm{WER}_{\mathrm{P}}+\mathrm{WER}_{\mathrm{S}}=\mathrm{WUE}_{\text {intP }} / \mathrm{WUE}_{\text {monoP }}+\mathrm{WUE}$ ints $/$ WUE monos

Where: $\mathrm{WUE}_{\text {intP }}=\left(\mathrm{Y}_{\text {intP }} / \mathrm{WU}_{\text {int }}\right), \mathrm{WUE}_{\text {monoP }}=\left(\mathrm{Y}_{\text {monoP }}\right.$ $\left./ \mathrm{WU}_{\text {monoP }}\right), \mathrm{WUE}_{\mathrm{intS}}=\left(\mathrm{Y}_{\mathrm{ints}} / \mathrm{WU}_{\mathrm{int}}\right)$ and $\mathrm{WUE}_{\text {monos }}=$ ( $\mathrm{Y}_{\text {monos }} / \mathrm{WU}$ monos $)$

Where: $\mathrm{WUE}_{\text {monoP }}$ and $\mathrm{WUE}_{\mathrm{monos}}$ are the water use efficiencies of monocultures of species peanut and sunflower. $\mathrm{WUE}_{\text {int,P }}$ and $\mathrm{WUE}_{\text {int,S }}$ are water use efficiencies of species peanut and sunflower in the intercrop. These WUEs are calculated as the yield of crop peanut or sunflower per unit of total water used in the intercrop. $\mathrm{Y}$ is yield, $\mathrm{WU}_{\text {int }}$ is the actual evapotranspiration of whole intercropping system, 
$\mathrm{WU}_{\text {mono,P }}$ and $\mathrm{WU}_{\mathrm{mono}, \mathrm{S}}$ are the actual evapotranspiration of crops peanut and sunflower in monocultures.

\section{Cereal units:}

The cereal units (CUs) for peanut and sunflower crops were calculated by Brockaus (1962) as Each 100 $\mathrm{kg}$ of seeds of both crops equals 2 units.

\section{Water use efficiency (WUE):}

Water use efficiency (WUE, kg yield or cereal unit $\mathrm{mm}^{-1}$ ) reported here as the ratio of crop yield (Y) in $\mathrm{kg}$ or cereal unit to water consumptive use ( $\mathrm{mm}$ ) according to (Stanhill, 1986):

$\mathrm{WUE}=\mathrm{Y}\left(\mathrm{kg}\right.$ or cereal unit ha $\left.{ }^{-1}\right) / \mathrm{CU}\left(\mathrm{mm} \mathrm{ha}^{-1}\right)$ where:

$\mathrm{Y}=$ Crop yield in $\mathrm{kg}$ or cereal unit per $\mathrm{ha}^{-1}$.

$\mathrm{CU}=$ Water consumed during the growing season $(\mathrm{mm}$ $\left.\mathrm{ha}^{-1}\right)$.

\section{Crop water productivity (WP):}

The WP is defined as crop yield expressed in $\mathrm{kg}$ or cereal units per unit applied irrigation water (Zhang, 2003) that is given as follow:

$\mathrm{WP}=$ crop yield $\left(\mathrm{kg}\right.$ or cereal unit ha $\left.{ }^{-1}\right) /$ Applied

irrigation water $\left(\mathrm{mm} \mathrm{ha}^{-1}\right)$

\section{Competitive relationships and yield advantages:}

Land equivalent ratio: LER is the relative land area under sole crops that is required to produce the yields achieved in intercropping. This was determined according to Willey (1979):

$$
\mathrm{LER}=\mathrm{Yab} / \mathrm{Yaa}+\mathrm{Yba} / \mathrm{Ybb}
$$

where: Yaa $=$ Pure stand yield of crop (peanut), Ybb = Pure stand yield of crop (sunflower). Yab $=$ Mixture yield of peanut (when combined with sunflower), Yba = Mixture yield of sunflower (when combined with peanut).

Aggressivity (A): is another index represents a simple measure of how much the relative yield increase in crop $a$ is greater than that of crop $b$ in an intercropping system. Aggressivity values were determined according to Mc-Gilchrist (1965):

$$
\begin{aligned}
& \mathrm{Aab}=[\mathrm{Yab} /(\mathrm{YaaxZab})]-[\mathrm{Yba} /(\mathrm{YbbxZba})] \\
& \mathrm{Aba}=[\mathrm{Yba} /(\mathrm{YbbxZba})]-[\mathrm{Yab} /(\mathrm{YaaxZab})]
\end{aligned}
$$

where: $\mathrm{Aab}$ and $\mathrm{Aba}=\mathrm{Aggressivity}$ value for peanut and sunflower, respectively.

$\mathrm{zab}=$ Sown proportion of peanut (in mixture with sunflower).

zba=Sown proportion of sunflower (in mixture with peanut).

If $\mathrm{Aab}=0$, both crops are equally competitive, if $\mathrm{Aab}$ is positive, a is dominant, if $\mathrm{Aab}$ is negative $\mathrm{a}$ is dominated crop.

\section{Total and net income:}

Total return from each treatment was calculated in Egyptian pound (L.E. 9040 and 4765/ton) for peanut and sunflower, respectively, as an average for the two seasons (Bulletin of Statistical Cost Production and Net Return, 2016).

Net income $=$ Total income $-($ fixed cost of peanut + variable cost of sunflower).

\section{Statistical analysis:}

Data were statistically analyzed according to the technique of analysis of variance (ANOVA) as published by Gomez and Gomez (1984). Means of the treatments were compared using Least Significant Difference (LSD) at 5\% level of significance as developed by Waller and Duncan (1969).

\section{RESULTS AND DISCUSSION}

\section{Water distribution uniformity}

The distribution uniformity values of irrigation water for the both growing seasons were 78 and $80 \%$ for the two tests conducted at the beginning of each growing season, respectively. The obtained results showed a little increase in DU values in the second season as compared to the first season. This trend of results was similar to that obtained by Taha (2012 and 2013).

Effect of irrigation treatments, intercropping patterns and their interaction on light intensity $\%$ at middle and bottom of peanut and sunflower plants:

Light intensity $\%$ at the middle and bottom of the peanut and sunflower plants were influenced $(p<0.05)$ by the irrigation treatments and intercropping patterns, with some exceptions. This observation hold true in both seasons (Table 3). Deficit irrigation at 0.8 of ETo significantly increased light transmission at the middle and bottom of two crops compared to other irrigation treatments. Meanwhile, increasing water irrigation to 1.2 of ETo significantly intercepted the most light and transmitted the least. These results may be due to plants irrigated with 1.2 or 1.0 of ETo produced greater canopy therefore had greater light intercepted and low light intensity\%. These results here were accordance with those obtained by Loomis and Connor (2002), Langeroodi et al. (2014) and Adeboye et al. (2016).

Light intensity $\%$ at the middle and bottom of the plants were influenced $(\mathrm{p}<0.05)$ by the intercropping patterns in both seasons, except light intensity at the bottom of peanut plants in second season only. For peanut, light transmission in sole peanut at middle and bottom of the plants was significantly higher compared to other patterns. the presence of sunflower with peanut plants at high density P3 patterns markedly reduced light transmission by 19.47 and $18.80 \%$ at the middle and by 
Table 3. Effect of irrigation treatments, intercropping patterns and their interaction on light intensity $\%$ of peanut and sunflower plants in 2016 and 2017 seasons

\begin{tabular}{|c|c|c|c|c|c|c|c|c|c|}
\hline \multirow{3}{*}{ Treatme } & \multirow{3}{*}{ Trait } & \multicolumn{4}{|c|}{ Light intensity $\%$ of peanut at } & \multicolumn{4}{|c|}{ Light intensity \% of sunflower at } \\
\hline & & \multicolumn{2}{|c|}{ middle of the plant } & \multicolumn{2}{|c|}{ bottom of the plant } & \multicolumn{2}{|c|}{ middle of the plant } & \multicolumn{2}{|c|}{ bottom of the plant } \\
\hline & & 2016 & 2017 & 2016 & 2017 & 2016 & 2017 & 2016 & 2017 \\
\hline \multicolumn{10}{|c|}{ Irrigation treatment } \\
\hline \multicolumn{2}{|c|}{ I1 1.2 of ETo } & 9.97 & 10.12 & 5.43 & 5.24 & 32.55 & 30.81 & 12.55 & 9.11 \\
\hline \multicolumn{2}{|c|}{ I2 1.0 of ETo } & 10.83 & 10.80 & 5.96 & 5.95 & 36.90 & 35.89 & 13.87 & 12.84 \\
\hline \multicolumn{2}{|c|}{ I3 0.8 of ETo } & 12.11 & 12.77 & 6.08 & 6.68 & 40.72 & 39.56 & 15.18 & 16.21 \\
\hline \multicolumn{2}{|c|}{ LSD at $5 \% \mathrm{~A}$} & 2.07 & 1.99 & 0.60 & $\mathbf{0 . 3 3}$ & 1.99 & 0.24 & 2.15 & $\mathbf{0 . 3 3}$ \\
\hline \multicolumn{10}{|c|}{ Intercropping pattern } \\
\hline \multicolumn{2}{|c|}{$\mathrm{P} 1(100 \% \mathrm{P}+25 \% \mathrm{~S})$} & 11.35 & 11.69 & 6.04 & 6.13 & 39.92 & 37.78 & 15.49 & 15.94 \\
\hline \multicolumn{2}{|c|}{ P2 (100\%P+33\% S) } & 10.92 & 11.17 & 5.64 & 5.86 & 38.43 & 35.83 & 14.46 & 10.17 \\
\hline \multicolumn{2}{|c|}{ P3 (100\%P+50\% S) } & 9.64 & 9.89 & 5.05 & 5.27 & 35.72 & 35.45 & 9.52 & 9.17 \\
\hline \multicolumn{2}{|c|}{ Sole crop } & 11.97 & 12.18 & 6.56 & 6.57 & 32.82 & 32.63 & 15.99 & 15.59 \\
\hline \multicolumn{2}{|c|}{ LSD at $5 \% \mathrm{~B}$} & 0.57 & 0.22 & 0.29 & N.S & 0.29 & 0.18 & 0.19 & 0.31 \\
\hline \multicolumn{10}{|c|}{ Interaction } \\
\hline \multirow{4}{*}{$\begin{array}{c}\text { I1 } \\
1.2 \text { of } \\
\text { ETo }\end{array}$} & $\mathrm{P} 1$ & 10.33 & 10.58 & 5.64 & 5.20 & 35.74 & 33.17 & 14.17 & 12.33 \\
\hline & $\mathrm{P} 2$ & 9.94 & 10.06 & 5.25 & 5.35 & 34.26 & 31.22 & 13.14 & 6.56 \\
\hline & $\mathrm{P} 3$ & 8.74 & 8.78 & 4.66 & 4.55 & 31.55 & 30.84 & 8.20 & 5.56 \\
\hline & Sole crop & 10.87 & 11.07 & 6.16 & 5.85 & 28.65 & 28.02 & 14.67 & 11.98 \\
\hline \multirow{4}{*}{$\begin{array}{c}\mathrm{I} 2 \\
1.0 \text { of } \\
\text { ETo }\end{array}$} & $\mathrm{P} 1$ & 11.23 & 11.26 & 6.18 & 6.34 & 40.10 & 38.25 & 15.70 & 16.06 \\
\hline & $\mathrm{P} 2$ & 10.76 & 10.74 & 5.77 & 5.45 & 38.60 & 36.30 & 14.56 & 10.29 \\
\hline & P3 & 9.40 & 9.46 & 5.19 & 5.24 & 35.90 & 35.92 & 9.33 & 9.30 \\
\hline & Sole crop & 11.93 & 11.75 & 6.70 & 6.77 & 33.00 & 33.10 & 15.89 & 15.71 \\
\hline \multirow{4}{*}{$\begin{array}{c}\mathrm{I} 3 \\
0.8 \text { of } \\
\text { ETo }\end{array}$} & $\mathrm{P} 1$ & 12.49 & 13.23 & 6.30 & 6.85 & 43.92 & 41.92 & 16.60 & 19.44 \\
\hline & $\mathrm{P} 2$ & 12.06 & 12.71 & 5.90 & 6.78 & 42.43 & 39.97 & 15.68 & 13.67 \\
\hline & $\mathrm{P} 3$ & 10.78 & 11.43 & 5.30 & 6.00 & 39.71 & 39.59 & 11.04 & 12.66 \\
\hline & Sole crop & 13.11 & 13.72 & 6.82 & 7.09 & 36.81 & 36.77 & 17.41 & 19.08 \\
\hline \multicolumn{2}{|c|}{ LSD at $5 \%$ A $\times$ B } & 0.99 & 0.55 & 0.50 & N.S & N.S & 0.31 & N.S & N.S \\
\hline
\end{tabular}

23.02 and $19.79 \%$ at bottom of the plant, respectively, in the two seasons relative to sole peanut. These data indicate that intercepted solar radiation by peanut plant was affected negatively by shading effect of sunflower.

On the other hand, light transmittance at the middle of solid sunflower plants was significantly reduction by $17.79,14.60$ and $8.12 \%$ and $13.63,8.93$ and $7.95 \%$ compared to P1, P2 and P3 intercropping patterns, respectively, in 2016 and 2017 seasons. Meanwhile, the light intensity \% at the bottom of the sunflower plants in P2 and P3 intercropping pattern was the lowest compared with sole sunflower. Differences in their vertical arrangement of foliage and canopy architecture among inter crops indicate differ in light transmission compared to sole crops. As concluded by Awal et al. (2006) and Jiao et al. (2008).

Interaction effect between irrigation treatments and intercropping had significantly affected on light intensity $\%$ at middle of peanut plants in two seasons, bottom of peanut plants in first season and at the middle of sunflower plants in second season (Table 3).
Intercropping $25 \%$ of sunflower under deficit irrigation had the highest values of light intensity \%. Intercepted photosynthetically active radiation corresponds to the size of plant canopy. These results here were accordance with those obtained by Loomis and Connor (2002), Langeroodi et al. (2014) and Adeboye et al. (2016).

Effect of irrigation treatments, intercropping patterns and their interaction on growth, yield and its attributes of peanut and sunflower:

Peanut:

Plant height, number and weight of pods/plant, seeds weight/plant:

As seen in Table 4, all studied characters of peanut influenced $(\mathrm{P}<0.05)$ by irrigation treatments, intercropping patterns and their interaction in the two seasons.

Plant height, number and weight of pods/plant, seeds weight/plant significantly decreased by deficit irrigation (0.8 of ETo) compared to other irrigation treatments. While the greatest values of the previous 
traits were related with 1.2 of ETo. This is to be expected since water plays an important role in plants and deficit irrigation can have a deleterious effect on most physical processes (Haro et al. 2008, Asik and Yildiz 2015, Feng et al., 2016). It is worth to noting that, No.of pods/plant value was higher in the second growing season as compared with the first season, this attributed to distribution uniformity increased in the second growing season as compared to the first under sprinkler irrigation system (Taha, 2012).

Data in Table 4 revealed that intercropping patterns had a significant effect on these traits in both seasons. All traits were decreased by the intercropping compared with sole peanut, except plant height in both seasons. Intercropping sunflower at the high density P3 was produced the maximal plant height, contrary, number of pods and weight/plant, seeds weight/plant were reached their minimal. The shading effect of peanut by the sunflower plant (taller) may also have contributed to reduction in the yield components of peanut and increasing internode length by reducing the light intensity $\%$ of the lower growing plant (as shown in
Table 3). Similar results were reported by (El-Sawy et al., 2006 and Nassar et al., 2008).

Interaction between irrigation treatments and intercropping patterns had a significant effect on plant height, number of pods/plant in both seasons, and seeds weight/plant in 2016 season. Increasing sunflower plant density from 25 up to $50 \%$ under irrigation treatment 1.2 of ETo achieved the tallest plants. While the shortest plants of peanut were detected under deficit irrigation ( 0.8 of ETo) with sole peanut. The highest values of No.of pods/plant and seed weight/plant were detected with irrigation treatment 1.2 of ETo and sole peanut, while irrigated P3 pattern with 0.8 of ETo achieved the lowest values for these traits.

\section{0-pod weight, 100-seed weight, pod and oil yields} and oil $\%$.

100-pod weight, 100- seed weight and pod and oil yields/ha were increased $(\mathrm{P}<0.05)$ by increasing water irrigation from 0.8 up to 1.2 of ETo, whereas the highest oil \% was detected with irrigation treatment 1.0 of ETo in both seasons as shown in Table (5). The lowest values of the above mentioned characters were obtained from irrigation treatment at 0.8 of ETo.

Table 4. Effect of irrigation treatments, intercropping patterns and their interaction on plant height and yield components of peanut in 2016 and 2017 seasons

\begin{tabular}{|c|c|c|c|c|c|c|c|c|c|}
\hline \multirow{2}{*}{\multicolumn{2}{|c|}{$\begin{array}{ll} & \text { Trait } \\
\text { Treatment }\end{array}$}} & \multicolumn{2}{|c|}{$\begin{array}{c}\text { Plant height } \\
(\mathrm{Cm})\end{array}$} & \multicolumn{2}{|c|}{ No.of pods /plant } & \multicolumn{2}{|c|}{$\begin{array}{l}\text { Pods weight } \\
\text { /Plant (g) }\end{array}$} & \multicolumn{2}{|c|}{$\begin{array}{c}\text { Seeds weight } \\
\text { /plant (g) }\end{array}$} \\
\hline & & 2016 & 2017 & 2016 & 2017 & 2016 & 2017 & 2016 & 2017 \\
\hline \multicolumn{10}{|c|}{ Irrigation treatment } \\
\hline \multicolumn{2}{|c|}{ I1 1.2 of ETo } & 51.25 & 44.25 & 15.18 & 16.34 & 22.21 & 23.01 & 13.81 & 14.44 \\
\hline \multicolumn{2}{|c|}{ I2 1.0 of ETo } & 50.50 & 42.25 & 14.90 & 15.17 & 21.94 & 22.29 & 13.22 & 13.42 \\
\hline \multicolumn{2}{|c|}{ I3 0.8 of ETo } & 43.96 & 32.33 & 13.63 & 13.94 & 19.24 & 20.24 & 11.01 & 11.64 \\
\hline \multicolumn{2}{|c|}{ LSD at $5 \% \mathrm{~A}$} & 1.55 & 2.34 & 1.09 & 0.98 & 1.06 & 0.39 & 0.94 & $\mathbf{0 . 7 0}$ \\
\hline \multicolumn{10}{|c|}{ Intercropping pattern } \\
\hline \multicolumn{2}{|c|}{$\mathrm{P} 1(100 \% \mathrm{P}+25 \% \mathrm{~S})$} & 48.11 & 38.34 & 15.03 & 15.93 & 21.73 & 22.05 & 13.48 & 13.74 \\
\hline \multicolumn{2}{|c|}{$\mathrm{P} 2(100 \% \mathrm{P}+33 \% \mathrm{~S})$} & 50.39 & 40.00 & 13.85 & 14.17 & 20.45 & 21.55 & 11.87 & 12.61 \\
\hline \multicolumn{2}{|c|}{$\mathrm{P} 3(100 \% \mathrm{P}+50 \% \mathrm{~S})$} & 55.06 & 43.56 & 12.72 & 13.13 & 18.55 & 19.45 & 10.24 & 10.94 \\
\hline \multicolumn{2}{|c|}{ P4 (sole peanut) } & 40.72 & 36.55 & 16.68 & 17.36 & 23.78 & 24.32 & 15.13 & 15.38 \\
\hline \multicolumn{2}{|c|}{ LSD at $5 \% \mathrm{~B}$} & 1.80 & 2.10 & 0.86 & 1.15 & 1.41 & 0.76 & 0.92 & 0.58 \\
\hline \multicolumn{10}{|c|}{ Interaction } \\
\hline \multirow{5}{*}{$\begin{array}{c}\mathrm{I} 1 \\
1.2 \mathrm{ETo}\end{array}$} & $\mathrm{P} 1$ & 49.17 & 43.67 & 15.92 & 17.19 & 22.94 & 23.25 & 14.79 & 15.03 \\
\hline & $\mathrm{P} 2$ & 51.83 & 43.67 & 14.36 & 15.23 & 21.96 & 22.58 & 13.18 & 13.77 \\
\hline & P3 & 58.83 & 47.67 & 12.51 & 14.60 & 19.70 & 21.18 & 11.03 & 12.28 \\
\hline & $\mathrm{P} 4$ & 45.17 & 42.00 & 17.92 & 18.33 & 24.22 & 25.01 & 16.25 & 16.68 \\
\hline & $\mathrm{P} 1$ & 51.00 & 39.67 & 15.60 & 16.00 & 22.52 & 22.61 & 14.01 & 14.15 \\
\hline \multirow{4}{*}{$\begin{array}{c}\mathrm{I} 2 \\
1.0 \text { ETo }\end{array}$} & $\mathrm{P} 2$ & 54.67 & 43.67 & 14.03 & 14.07 & 21.28 & 21.81 & 12.44 & 12.81 \\
\hline & P3 & 56.67 & 47.33 & 13.33 & 13.33 & 18.54 & 18.94 & 10.46 & 10.59 \\
\hline & P4 & 39.67 & 38.33 & 16.65 & 17.28 & 25.41 & 25.79 & 15.96 & 16.12 \\
\hline & P1 & 44.17 & 31.67 & 13.56 & 14.60 & 19.72 & 20.30 & 11.63 & 12.03 \\
\hline \multirow{3}{*}{$\begin{array}{c}\text { I3 } \\
0.8 \text { ETo }\end{array}$} & $\mathrm{P} 2$ & 44.67 & 32.67 & 13.15 & 13.20 & 18.11 & 20.26 & 10.00 & 11.26 \\
\hline & P3 & 49.67 & 35.67 & 12.33 & 11.47 & 17.41 & 18.22 & 9.22 & 9.94 \\
\hline & P4 & 37.33 & 29.33 & 15.47 & 16.48 & 21.72 & 22.17 & 13.19 & 13.34 \\
\hline \multicolumn{2}{|c|}{ LSD at $5 \% \mathrm{~A} \times \mathrm{xB}$} & 3.11 & 3.63 & 1.49 & 1.98 & N.S & N.S & 1.60 & N.S \\
\hline
\end{tabular}


The reducing in pod yield $(\mathrm{P}<0.05)$ due to irrigation peanut with 0.8 of ETo compared to high water irrigation treatments 1.2 of ETo were $13.62 \%$ and $12.19 \%$, respectively, in first and second seasons. Oil yield reduction was $15.01 \%$ and $12.79 \%$ with irrigating peanut with 0.8 ETo compared to 1.2 of ETo, respectively, in both seasons. This trend reflects the effect of more available soil moisture in root zone under 1.2 of ETo throughout the growing season. Since increasing water irrigation accelerated the vegetative growth of peanut and therefore encouraged cell division and meristematic activity by good absorption of nutrients with high levels of available moisture (Hsiao 1973). These results confirmed results of Haro et al. (2008), Rowland et al. (2012) and Asik and Yildiz (2015).

Solid peanut recorded the highest values of 100-pod weight, 100- seed weight and pod yield and oil yield/ha compared with all intercropping patterns and differences were significantly $(\mathrm{p}<0.05)$ in the two seasons. The reduction in pod yield for P1, P2 and P3 were $8.17,12.74$ and $16.50 \%$ and $9.83,12.77$ and

Table 5. Effect of irrigation treatments, intercropping patterns and their interaction on yield and its components of peanut in 2016 and 2017 seasons

\begin{tabular}{|c|c|c|c|c|c|c|c|c|c|c|c|}
\hline \multirow{2}{*}{\multicolumn{2}{|c|}{ Trait }} & \multicolumn{2}{|c|}{$\begin{array}{l}\text { 100-pod weight } \\
\text { (g) }\end{array}$} & \multicolumn{2}{|c|}{$\begin{array}{l}\text { 100-seed weight } \\
\text { (g) }\end{array}$} & \multicolumn{2}{|c|}{$\begin{array}{c}\text { Pod yield } \\
\text { (ton/ ha) }\end{array}$} & \multicolumn{2}{|c|}{$\begin{array}{l}\text { Oil yield } \\
\text { (ton /ha) }\end{array}$} & \multicolumn{2}{|c|}{$\begin{array}{c}\text { Oil } \\
\%\end{array}$} \\
\hline & & 2016 & 2017 & 2016 & 2017 & 2016 & 2017 & 2016 & 2017 & 2016 & 2017 \\
\hline \multicolumn{12}{|c|}{ Irrigation } \\
\hline \multicolumn{2}{|c|}{ I1 1.2 of ETo } & 140.06 & 137.72 & 88.62 & 91.10 & 3.179 & 3.184 & 1.039 & 1.024 & 49.05 & 48.15 \\
\hline \multicolumn{2}{|c|}{ I2 1.0 of ETo } & 137.11 & 134.03 & 86.33 & 87.09 & 3.083 & 3.130 & 1.008 & 1.004 & 49.08 & 48.30 \\
\hline \multicolumn{2}{|c|}{ I3 0.8 of ETo } & 131.72 & 132.89 & 77.93 & 83.64 & 2.746 & 2.796 & 0.883 & 0.893 & 48.26 & 47.93 \\
\hline \multicolumn{2}{|c|}{ LSD at $5 \% \mathrm{~A}$} & 3.73 & 2.46 & 1.88 & 0.92 & 0.020 & 0.040 & 0.018 & $\mathbf{0 . 0 2 2}$ & 0.32 & 0.36 \\
\hline \multicolumn{12}{|c|}{ Intercropping pattern } \\
\hline \multicolumn{2}{|c|}{$\mathrm{P} 1(100 \% \mathrm{P}+25 \% \mathrm{~S})$} & 139.14 & 136.66 & 85.90 & 91.32 & 3.003 & 3.035 & 0.977 & 0.974 & 48.76 & 48.12 \\
\hline \multicolumn{2}{|c|}{$\mathrm{P} 2(100 \% \mathrm{P}+33 \% \mathrm{~S})$} & 134.44 & 133.06 & 82.65 & 86.16 & 2.903 & 2.936 & 0.950 & 0.951 & 49.06 & 48.57 \\
\hline \multicolumn{2}{|c|}{$\mathrm{P} 3(100 \% \mathrm{P}+50 \% \mathrm{~S})$} & 128.22 & 124.61 & 77.34 & 78.63 & 2.778 & 2.809 & 0.910 & 0.910 & 49.08 & 48.59 \\
\hline \multicolumn{2}{|c|}{ P4 (sole peanut) } & 143.39 & 137.24 & 91.29 & 92.99 & 3.327 & 3.366 & 1.071 & 1.060 & 48.27 & 47.22 \\
\hline \multicolumn{2}{|c|}{ LSD at $5 \% \mathrm{~B}$} & 2.90 & 5.69 & 2.75 & 0.85 & 0.028 & 0.158 & 0.004 & 0.017 & 0.12 & 0.18 \\
\hline \multicolumn{12}{|c|}{ Interaction } \\
\hline \multirow{4}{*}{$\begin{array}{c}\mathrm{I} 1 \\
1.2 \%\end{array}$} & $\mathrm{P} 1$ & 144.33 & 139.50 & 92.06 & 94.78 & 3.192 & 3.204 & 1.045 & 1.027 & 48.79 & 48.13 \\
\hline & $\mathrm{P} 2$ & 138.32 & 137.62 & 87.04 & 90.28 & 3.115 & 3.128 & 1.023 & 1.020 & 49.19 & 48.60 \\
\hline & $\mathrm{P} 3$ & 130.62 & 133.31 & 81.81 & 84.52 & 2.967 & 2.937 & 0.988 & 0.961 & 49.25 & 48.60 \\
\hline & $\mathrm{P} 4$ & 146.97 & 140.46 & 93.57 & 94.81 & 3.443 & 3.465 & 1.103 & 1.090 & 48.95 & 47.27 \\
\hline \multirow{5}{*}{$\begin{array}{c}\mathrm{I} 2 \\
1.0 \%\end{array}$} & $\mathrm{P} 1$ & 139.44 & 137.36 & 89.20 & 91.26 & 3.135 & 3.167 & 1.020 & 1.016 & 49.10 & 48.07 \\
\hline & $\mathrm{P} 2$ & 135.21 & 134.03 & 84.37 & 85.71 & 3.000 & 3.035 & 0.984 & 0.983 & 49.25 & 48.90 \\
\hline & P3 & 129.36 & 126.59 & 77.99 & 78.42 & 2.833 & 2.892 & 0.930 & 0.937 & 49.93 & 49.07 \\
\hline & P4 & 144.43 & 138.15 & 93.78 & 92.97 & 3.361 & 3.425 & 1.097 & 1.079 & 48.04 & 47.17 \\
\hline & $\mathrm{P} 1$ & 133.65 & 136.66 & 76.45 & 87.91 & 2.681 & 2.735 & 0.865 & 0.878 & 48.40 & 48.17 \\
\hline \multirow{3}{*}{$\begin{array}{c}\mathrm{I} 3 \\
0.8 \%\end{array}$} & $\mathrm{P} 2$ & 129.79 & 133.06 & 76.54 & 82.50 & 2.592 & 2.645 & 0.842 & 0.850 & 48.75 & 48.20 \\
\hline & P3 & 124.67 & 124.61 & 72.22 & 72.96 & 2.533 & 2.597 & 0.812 & 0.833 & 48.07 & 48.10 \\
\hline & $\mathrm{P} 4$ & 138.77 & 137.24 & 86.51 & 91.18 & 3.176 & 3.208 & 1.012 & 1.010 & 47.81 & 47.23 \\
\hline \multicolumn{2}{|c|}{ LSD at $5 \% \mathrm{~A} \times \mathrm{xB}$} & 9.53 & N.S & 4.74 & 3.71 & 0.052 & 0.286 & 0.050 & $\mathbf{0 . 0 2 9}$ & 0.25 & 0.32 \\
\hline
\end{tabular}

$16.55 \%$, respectively, in first and second season compared to solid peanut. The highest reduction in oil yield/ha were detected when intercropping sunflower at high density (50\%) P3. Since oil yield/h were decreased by $8.78,11.30$ and $15.03 \%$ (in 2016 season) and 8.11 , 10.28 and $14.15 \%$ (in 2017 season) under P1, P2 and P3 intercropping patterns compared to sole peanut, respectively. This reduction in peanut yield under intercropping could be due to inter-specific competition between the intercrop components for water, light, air and nutrients. Contrary, the highest values of oil $\%$ were detected with P3 compared to sole and the other intercropping patterns. These observations hold true in two seasons and are in accordance with those obtained by Sankaran and Kuppuswamy, (1992), El-sawy et al. (2006) and Abd El-Zaher et al. (2009).

The interaction revealed that maximum values of yield and its components were obtained when irrigated sole peanut plants with high amount of water irrigation 1.2 of ETo. Whereas, the minimum values of these traits were gained with P3 (100\% peanut $+50 \%$ sunflower) under deficit irrigation 0.8 of ETo. 
This was true since increasing water irrigation accelerated the vegetative growth of peanut and decreasing sunflower plant density associated with peanut, which resulting in low competitions on growth resources between peanut and sunflower plants. These results are harmony with those obtained by Lesoing and Francis (1999), Abd El-Zaher et al. (2009), Rowland et al. (2012) and Asik and Yildiz (2015).

\section{Sunflower:}

\section{Plant height, No.of leaves and head diameter and head weight:}

The results in Table 6 showed that the studied traits of sunflower were affected $(\mathrm{P}<0.05)$ by irrigation treatments, intercropping patterns and interaction in both seasons.

Plant height, number of leaves/plant, head diameter and head weight significantly increased with increasing water irrigation to 1.2 of ETo without significant differences between 1.2 and 1.0 of ETo for plant height in the two seasons. The lowest values of these traits were obtained from irrigating sunflower with 0.8 of ETo in two successive seasons, these results attributed to increasing water stress under irrigation treatment 0.80 of ETo. Since the increase of a mount irrigation water increased number and length of internodes as well as number of leaves/plant due to the promoting role of enough watering for cell division, expansion and enlargement (Nezami et al., 2008). These results confirmed results of Gholinezhad et al. (2009) and ElDakrourry (2015).

The previous mentioned traits were affected $(\mathrm{P} \leq$ 0.05 ) by intercropping patterns in both seasons (Table $6)$. The data indicated that there was relevance between sunflower density and plant height. The more sunflower plants in the area the taller stalks and more No.of leaves/plant were. Thus, sunflower in pure stand resulted in tallest plants and more leaves/plant compared to the other intercropping patterns. While head diameter and head weight behaved opposite trend. Maximum values of these traits were obtained by intercropping pattern P1 (100\% P+ 25\% S). This result might be due to increased intra-specific competition between sunflower plants for basic growth resources especially solar radiation, which resulted in marked elongation of the internodes of plants searching for more light and higher diminished in diameter and weight of head, under sole sunflower than intercropping patterns. These results are in agreement with those obtained by El-sawy et al. (2006), Nassar et al. (2008) and Abd El-Zaher et al. (2009).
Data listed in Table 6 clearly indicated that plant height, head diameter, head weight were influenced $(\mathrm{P} \leq$ $0.05)$ by interaction between irrigation treatments and intercropping patterns in both seasons. Solid sunflower gained the tallest plant heights under irrigation treatments 1.2 of ETo. While the highest head diameter and weight produced with intercropping pattern P1 under the same irrigation treatment. Whereas, intercropping pattern P1had the shortest plants compared with other treatments when irrigated with 0.8 of ETo. The lowest head diameter and weight were achieved by solid sunflower under deficit irrigation treatments 0.8 of ETo.

\section{Seed weight/head, 100-seed weight, seed and oil yield/ha and oil \%:}

Seed weight/head, 100-seed weight, seed and oil yield/ha and oil\% of sunflower affected $(\mathrm{P}<0.05)$ by irrigation treatments in both seasons as shown in (Table 7). Irrigation with amounts of water equals to 1.2 of ETo significantly increased seed weight/head, 100-seed weight, seed and oil yields/ha as compared to irrigation with amounts of water equals to 1.0 and 0.8 of ETo. Meanwhile, the lowest values were achieved when irrigated sunflower plants with 0.8 of ETo in both seasons. However, the highest oil content was achieved with 1.0 ETo followed by 1.2 then 0.8 of ETo in a descending order. The increase in seed and oil yield at 1.2 of ETo compared with 0.8 of ETo irrigation treatments were $25.02 \%$ and $22.69 \%$ for seed yield and 30.41 and $35.51 \%$ in first and second seasons, respectively. This result reflects the effect of distribution uniformity (DU) in increased applied irrigation water under 1.2 and 1.0 of ETo treatments compared of 0.8 of ETo and more available soil moisture in root zone. That is led to an increase in various physiological processes, higher rates of photosynthesis, number of leaves and flowers which in turn led to better seed development and higher seed and oil yields. These results are in harmony with those obtained by Gholinezhad et al. (2009) and Langeroodi et al. (2014) and El-Dakrourry (2015).

Intercropping patterns had significantly affected yield and its components in both seasons, except 100seed weight was not affected in the first season attributed to distribution uniformity increased irrigation water in second season (Table 7). Maximum values of seed weight/head and 100-seed weight were obtained by intercropping pattern P1 (25\% S), whereas, minimum values of these traits resulted from pure stand (P5). The improvement of light intensity \% in intercropping plots (Table 3) give rise to the raise of the photosynthetic rate of sunflower, which could be resulted the improvement 
of the yield components of sunflower compared with solid pattern (Nassar et al., 2006). Sunflower plant density per unit area is one of the major factors that determining seed and oil yield per unit area. Where intercropping sunflower with peanut in P1, P2 and P3 decreased $(\mathrm{P} \leq 0.05)$ seed yield per ha by $59.70,46.83$ and $32.59 \%$, while reduction in oil yield per ha were $60.89,47.82$ and $32.67 \%$ respectively, as compared with sole sunflower as average in the both seasons. However, intercropping sunflower with peanut increased seed oil content compared to sole sunflower. These results are in agreement with those obtained by El-sawy et al. (2006), Abd El-Zahr et al. (2009) and Abdel-Wahab and El Manzlawy (2016) Whereas, Kandel et al. (1996) showed that sunflower oil content was not influenced by intercropped legumes.

The previous mentioned traits significantly affected by interaction in both seasons as shown in Table (7). The heaviest seed weight /head and 100- seed weight were obtained from intercropping pattern P1 (25\% sunflower) under full irrigation 1.2 of ETo, while the lowest weight of these traits were achieved when

Table 6. Effect of irrigation treatments, intercropping patterns and their interaction on plant height, No.of leaves, head diameter and weight of sunflower in 2016 and 2017 seasons

\begin{tabular}{|c|c|c|c|c|c|c|c|c|c|}
\hline \multirow{2}{*}{\multicolumn{2}{|c|}{$\begin{array}{ll}\text { Trait } & \\
\text { Treatment } \\
\end{array}$}} & \multicolumn{2}{|c|}{$\begin{array}{c}\text { Plant height } \\
\text { Cm }\end{array}$} & \multicolumn{2}{|c|}{$\begin{array}{c}\text { No. of leaves } \\
\text { /Plant }\end{array}$} & \multicolumn{2}{|c|}{$\begin{array}{c}\text { Head diameter } \\
(\mathbf{c m})\end{array}$} & \multicolumn{2}{|c|}{$\begin{array}{c}\text { Head weight } \\
\text { (g) }\end{array}$} \\
\hline & & 2016 & 2017 & 2016 & 2017 & 2016 & 2017 & 2016 & 2017 \\
\hline \multicolumn{10}{|c|}{ Irrigation treatment } \\
\hline \multirow{2}{*}{\multicolumn{2}{|c|}{ I1 1.2 of ETo }} & 136.17 & 136.59 & 15.96 & 16.16 & 17.47 & 18.43 & 77.05 & 115.53 \\
\hline & I2 1.0 of ETo & 134.67 & 135.50 & 14.72 & 15.63 & 17.45 & 17.97 & 69.49 & 83.70 \\
\hline \multicolumn{2}{|c|}{ I3 0.8 of ETo } & 126.58 & 129.25 & 14.00 & 14.18 & 16.28 & 16.91 & 53.66 & 52.02 \\
\hline \multicolumn{2}{|c|}{ LSD at $5 \% \mathrm{~A}$} & 1.71 & 2.65 & 0.38 & 0.21 & 0.35 & $\mathbf{0 . 5 7}$ & 2.22 & 2.71 \\
\hline \multicolumn{10}{|c|}{ Intercropping pattern } \\
\hline \multicolumn{2}{|c|}{$\mathrm{P} 1(100 \% \mathrm{P}+25 \% \mathrm{~S})$} & 123.22 & 125.78 & 13.80 & 13.91 & 19.04 & 20.89 & 72.68 & 96.91 \\
\hline \multicolumn{2}{|c|}{$\mathrm{P} 2(100 \% \mathrm{P}+33 \% \mathrm{~S})$} & 128.56 & 130.78 & 14.54 & 15.06 & 17.80 & 18.68 & 68.85 & 88.60 \\
\hline \multicolumn{2}{|c|}{ P3 (100\% P+50\% S) } & 135.67 & 136.56 & 15.13 & 15.80 & 16.22 & 16.15 & 64.56 & 81.67 \\
\hline \multicolumn{2}{|c|}{ P5 sole sunflower } & 142.44 & 142.00 & 16.09 & 16.52 & 15.20 & 15.35 & 60.84 & 67.82 \\
\hline \multicolumn{2}{|c|}{ LSD at $5 \%$ B } & 2.36 & 2.11 & 0.65 & 0.47 & 0.48 & 0.61 & 1.65 & 2.07 \\
\hline \multicolumn{10}{|c|}{ Interaction } \\
\hline \multirow{4}{*}{$\begin{array}{l}\text { I1 } \\
1.2 \text { of } \\
\text { ETo }\end{array}$} & $\mathrm{P} 1$ & 123.67 & 126.00 & 14.88 & 14.75 & 19.07 & 21.73 & 87.87 & 123.53 \\
\hline & $\mathrm{P} 2$ & 132.33 & 134.67 & 15.61 & 15.9 & 18.40 & 19.27 & 78.46 & 122.27 \\
\hline & P3 & 142.33 & 139.67 & 16.2 & 16.63 & 16.40 & 16.93 & 72.87 & 120.33 \\
\hline & P5 & 146.33 & 146.00 & 17.15 & 17.36 & 16.00 & 15.80 & 69.00 & 96.00 \\
\hline \multirow{4}{*}{$\begin{array}{l}\mathrm{I} 2 \\
1.0 \text { of } \\
\text { ETo }\end{array}$} & $\mathrm{P} 1$ & 127.67 & 130.33 & 13.63 & 14.22 & 19.93 & 20.93 & 73.84 & 108.93 \\
\hline & $\mathrm{P} 2$ & 130.33 & 132.00 & 14.37 & 15.36 & 18.20 & 19.27 & 72.72 & 87.87 \\
\hline & P3 & 136.00 & 138.67 & 14.95 & 16.11 & 16.67 & 16.33 & 67.04 & 72.87 \\
\hline & P5 & 144.67 & 141.00 & 15.92 & 16.83 & 15.00 & 15.33 & 64.36 & 65.13 \\
\hline \multirow{4}{*}{$\begin{array}{c}\text { I3 } \\
0.8 \text { of } \\
\text { ETo }\end{array}$} & $\mathrm{P} 1$ & 118.33 & 121.00 & 12.91 & 12.76 & 18.13 & 20.00 & 56.33 & 58.27 \\
\hline & $\mathrm{P} 2$ & 123.00 & 125.67 & 13.65 & 13.92 & 16.80 & 17.50 & 55.37 & 55.67 \\
\hline & $\mathrm{P} 3$ & 128.67 & 131.33 & 14.24 & 14.66 & 15.60 & 15.20 & 53.77 & 51.80 \\
\hline & P5 & 136.33 & 139.00 & 15.2 & 15.38 & 14.60 & 14.93 & 49.17 & 42.33 \\
\hline \multicolumn{2}{|c|}{ LSD at $5 \% \mathrm{~A} \times \mathrm{B}$} & 4.09 & 3.66 & N.S & N.S & 0.49 & 0.53 & 2.69 & 3.58 \\
\hline
\end{tabular}

irrigated solid sunflower with 0.8 of ETo. On the other hand, solid planting produced the highest seed an oil yield/ha under different irrigation treatments compared with intercropping patterns. This result might be due to adequate moisture availability in the soil which might have led to increase various physiological processes, higher rates of photosynthesis, which in turn led to better seed development and higher seed and oil yields as well as seed and oil yields related to number of plants per unit area El-Dakrourry (2015) and Abd El-Zahr et al. (2009).

Effect of the tested treatments on applied irrigation water (AIW) and water consumptive use (WCU):

The depth of applied irrigation water in the 2016 and 2017 seasons under the 1.2, 1.0 and 0.8 ETo irrigation treatments were 451 and $439 \mathrm{~mm}$ (4510 and $4390 \mathrm{~m}^{3} / \mathrm{ha}$ ), 376 and $366 \mathrm{~mm}$ (3760 and $3660 \mathrm{~m}^{3} / \mathrm{ha}$ ) and 303 and $293 \mathrm{~mm} \mathrm{(3030} \mathrm{and} 2930 \mathrm{~m}^{3} / \mathrm{ha}$ ), respectively (Table 8 ). The difference between depths of applied irrigation water in the two seasons is due to changes in the efficiencies. 
Table 7. Effect of irrigation treatments, intercropping patterns and their interaction on seed weight/head, 100seed weight, seed and oil yields/ha and oil\% of sunflower in 2016 and 2017 seasons

\begin{tabular}{|c|c|c|c|c|c|c|c|c|c|c|c|}
\hline \multirow{2}{*}{ Treatme } & \multirow[t]{2}{*}{ Trait } & \multicolumn{2}{|c|}{$\begin{array}{l}\text { Seed weight } \\
\text { /head (g) }\end{array}$} & \multicolumn{2}{|c|}{$\begin{array}{c}\text { 100-seed weight } \\
\text { (g) }\end{array}$} & \multicolumn{2}{|c|}{$\begin{array}{c}\text { Seed yield } \\
\text { (ton/ha) }\end{array}$} & \multicolumn{2}{|c|}{$\begin{array}{c}\text { Oil Yield } \\
\text { (ton/ha) }\end{array}$} & \multicolumn{2}{|c|}{$\begin{array}{l}\text { Oil } \\
\%\end{array}$} \\
\hline & & 2016 & 2017 & 2016 & 2017 & 2016 & 2017 & 2016 & 2017 & 2016 & 2017 \\
\hline \multicolumn{12}{|c|}{ Irrigation treatment } \\
\hline \multicolumn{2}{|c|}{ I1 1.2 of ETo } & 42.39 & 47.66 & 5.55 & 6.11 & 1.529 & 1.590 & 0.639 & 0.664 & 41.47 & 40.91 \\
\hline \multicolumn{2}{|c|}{ I2 1.0 of ETo } & 38.29 & 41.75 & 5.58 & 5.88 & 1.478 & 1.574 & 0.622 & 0.660 & 41.78 & 41.76 \\
\hline \multicolumn{2}{|c|}{ I3 0.8 of ETo } & 30.11 & 32.33 & 4.37 & 5.12 & 1.223 & 1.296 & 0.490 & 0.516 & 40.19 & 40.04 \\
\hline \multicolumn{2}{|c|}{ LSD at $5 \% \mathrm{~A}$} & 1.67 & 0.64 & 0.94 & 0.21 & 0.072 & 0.042 & 0.004 & 0.010 & 0.16 & 0.30 \\
\hline \multicolumn{12}{|c|}{ Intercropping pattern } \\
\hline \multicolumn{2}{|c|}{$\mathrm{P} 1(100 \% \mathrm{P}+25 \% \mathrm{~S})$} & 44.44 & 51.00 & 5.73 & 6.35 & 0.865 & 0.925 & 0.350 & 0.374 & 40.47 & 40.56 \\
\hline \multicolumn{2}{|c|}{$\mathrm{P} 2(100 \% \mathrm{P}+33 \% \mathrm{~S})$} & 42.67 & 45.49 & 5.28 & 6.09 & 1.155 & 1.206 & 0.469 & 0.497 & 40.55 & 41.11 \\
\hline \multicolumn{2}{|c|}{$\mathrm{P} 3(100 \% \mathrm{P}+50 \% \mathrm{~S})$} & 34.30 & 38.16 & 5.00 & 5.83 & 1.454 & 1.540 & 0.613 & 0.633 & 41.96 & 41.02 \\
\hline \multicolumn{2}{|c|}{ P5 sole sunflower } & 27.30 & 27.66 & 4.66 & 4.54 & 2.166 & 2.275 & 0.902 & 0.949 & 41.61 & 40.92 \\
\hline \multicolumn{2}{|c|}{ LSD at $5 \% \mathrm{~B}$} & 1.10 & 1.00 & N.S & 1.20 & 0.064 & $\mathbf{0 . 0 5 7}$ & 0.005 & 0.011 & 0.11 & 0.20 \\
\hline \multicolumn{12}{|c|}{ Interaction } \\
\hline \multirow{4}{*}{$\begin{array}{c}\text { I1 } \\
1.2 \text { of } \\
\text { ETo }\end{array}$} & $\mathrm{P} 1$ & 52.25 & 61.06 & 6.24 & 6.72 & 0.990 & 1.037 & 0.399 & 0.418 & 40.30 & 40.30 \\
\hline & $\mathrm{P} 2$ & 47.37 & 53.99 & 5.22 & 6.58 & 1.180 & 1.222 & 0.479 & 0.498 & 40.57 & 40.77 \\
\hline & P3 & 38.33 & 44.71 & 5.66 & 6.12 & 1.648 & 1.703 & 0.703 & 0.706 & 42.68 & 41.47 \\
\hline & P5 & 31.62 & 30.87 & 5.07 & 5.01 & 2.298 & 2.396 & 0.973 & 1.033 & 42.34 & 43.10 \\
\hline \multirow{4}{*}{$\begin{array}{c}\mathrm{I} 2 \\
1.0 \text { of } \\
\text { ETo }\end{array}$} & $\mathrm{P} 1$ & 44.48 & 50.10 & 6.22 & 6.80 & 0.938 & 1.019 & 0.378 & 0.411 & 40.32 & 40.37 \\
\hline & $\mathrm{P} 2$ & 44.42 & 46.97 & 6.10 & 6.32 & 1.249 & 1.313 & 0.510 & 0.554 & 40.87 & 42.20 \\
\hline & P3 & 35.83 & 39.82 & 5.76 & 6.30 & 1.516 & 1.615 & 0.657 & 0.681 & 43.33 & 42.17 \\
\hline & P5 & 28.41 & 30.12 & 4.25 & 4.09 & 2.210 & 2.349 & 0.941 & 0.994 & 42.60 & 42.30 \\
\hline \multirow{4}{*}{$\begin{array}{c}\mathrm{I} 3 \\
0.8 \text { of } \\
\text { ETo }\end{array}$} & $\mathrm{P} 1$ & 36.60 & 41.85 & 4.72 & 5.52 & 0.668 & 0.719 & 0.272 & 0.293 & 40.79 & 41.00 \\
\hline & $\mathrm{P} 2$ & 33.22 & 35.51 & 4.52 & 5.37 & 1.037 & 1.084 & 0.417 & 0.438 & 40.20 & 40.37 \\
\hline & P3 & 28.74 & 29.96 & 4.17 & 5.07 & 1.199 & 1.301 & 0.478 & 0.512 & 39.88 & 39.37 \\
\hline & P5 & 21.88 & 21.99 & 4.07 & 4.52 & 1.989 & 2.080 & 0.793 & 0.820 & 39.88 & 39.43 \\
\hline \multicolumn{2}{|c|}{ LSD at $5 \%$ A $\times$ B } & 1.91 & 1.73 & 1.20 & 2.07 & 0.111 & 0.099 & 0.008 & 0.019 & 0.32 & 0.35 \\
\hline
\end{tabular}

Table 8. Applied irrigation water and water consumptive use as affected by irrigation treatments and intercropping pattern in the two growing seasons

\begin{tabular}{|c|c|c|c|c|c|}
\hline \multirow{2}{*}{\multicolumn{2}{|c|}{$\begin{array}{l}\text { Irrigation \& } \\
\text { Intercropping treat. }\end{array}$}} & \multicolumn{2}{|c|}{ Applied irrigation water (mm) } & \multicolumn{2}{|c|}{ Water consumptive use (mm) } \\
\hline & & 2016 & 2017 & 2016 & 2017 \\
\hline \multirow{5}{*}{ 1.2 ETo } & $\mathrm{P} 1$ & 451 & 439 & 395 & 395 \\
\hline & $\mathrm{P} 2$ & 451 & 439 & 392 & 401 \\
\hline & P3 & 451 & 439 & 403 & 415 \\
\hline & $\mathrm{P} 4$ & 451 & 439 & 343 & 350 \\
\hline & $\mathrm{P} 5$ & 451 & 439 & 271 & 278 \\
\hline \multirow{5}{*}{ 1.0 ETo } & $\mathrm{P} 1$ & 376 & 366 & 322 & 329 \\
\hline & $\mathrm{P} 2$ & 376 & 366 & 327 & 334 \\
\hline & P3 & 376 & 366 & 336 & 344 \\
\hline & $\mathrm{P} 4$ & 376 & 366 & 293 & 301 \\
\hline & P5 & 376 & 366 & 251 & 258 \\
\hline \multirow{5}{*}{0.8 ETo } & $\mathrm{P} 1$ & 303 & 293 & 259 & 263 \\
\hline & $\mathrm{P} 2$ & 303 & 293 & 263 & 267 \\
\hline & P3 & 303 & 293 & 270 & 278 \\
\hline & $\mathrm{P} 4$ & 303 & 293 & 236 & 240 \\
\hline & P5 & 303 & 293 & 203 & 206 \\
\hline
\end{tabular}

$\mathrm{P} 1=100 \%$ peanut $+25 \%$ sunflower, $\mathrm{P} 2=100 \%$ peanut $+33 \%$ sunflower, $\mathrm{P} 3=100 \%$ peanut $+50 \%$ sunflower, $\mathrm{P} 4=$ sole peanut, $\mathrm{P} 5=$ sole sunflower 
Regarding to the water consumptive use, results indicated that increasing plant density and amounts of irrigation water increased water consumption. Also, WCU values tended to increase in the second growing season compared to the first growing season as a result of increasing water distribution uniformity. Data in Table (8) indicated that the highest values of seasonal water consumptive use were 403 and $415 \mathrm{~mm}$ obtained under irrigation 1.2 ETo and intercropping pattern P3 $(100 \% \mathrm{P}+50 \% \mathrm{~S})$ in the first and second seasons, respectively. The increase in water consumptive use was due to increasing plant density and root distributions in surface soil for the P3 pattern compared to the other patterns. Similar results were obtained by Abd El- Hafez et al. (2002).

\section{Water use efficiency (WUE) and Water Equivalent Ratio (WER):}

The results in Table (9) showed that, under all irrigation treatments, total WUE $(\mathrm{kg} / \mathrm{mm})$ values of intercropping patterns were higher than sole peanut $(\mathrm{P} 4)$ or sunflower (P5). The WUE values of peanut were higher than those of sunflower due to plant density of peanut. Increasing sunflower ratio in intercropping were increased water use efficiency for sunflower $\left(\mathrm{WUE}_{\mathrm{s}}\right.$ ) and total WUE, but reduced water use efficiency of peanut crop ( $\left(\mathrm{WE}_{\mathrm{p}}\right)$. This reduction could be due to the competition between the intercrop components for water with direct effect on the produced yield (Metwally et al., 2017). The highest values of total WUE (13.82 and $14.02 \mathrm{~kg} / \mathrm{mm})$ were detected with P3 $(100 \% \mathrm{P}+50 \% \mathrm{~S})$ under irrigation treatment I3 (0.8 ETo) in 2016 and 2017 seasons, respectively. Similarly, all values of water equivalent ratio (WER) of intercropping patterns were greater than 1, which indicated that the water utilization efficiency of the intercropping was higher than that of sole pattern. The highest WER values (1.25 and 1.26) were recorded with $\mathrm{P} 3(100 \% \mathrm{P}+50 \% \mathrm{~S})$ under the 1.0 ETo irrigation treatment. While, the lowest values (1.03 and 1.05) were detected with $\mathrm{P} 1(100 \% \mathrm{P}+25 \% \mathrm{~S})$ when irrigated with 0.8 ETo, in both seasons, respectively. The above results indicated that the intercropping can utilize irrigation water more efficiently than monoculture by about 25 and $26 \%$. These results were confirmed with what was found by Feng et al. (2016).

Water use efficiency (WUE) calculated using the cereal units as affected by irrigation treatments and intercropping patterns:

Data in Table (10) showed that the highest water use efficiency values $(0.214$ and $0.218 \mathrm{CUs} / \mathrm{mm}$ of applied water) were obtained for the irrigation treatments 0.8 ETo with P3 (100\% peanut $+50 \%$ sunflower) in the first and second seasons, respectively. The lowest water use efficiency values $(0.134$ and $0.132 \mathrm{CUs} / \mathrm{mm}$ of applied water) were obtained for the irrigation treatments 1.2 ETo with sole peanut in the two seasons. It is worth to noting that, irrigation treatment I3 (0.8 of ETo) achieved the highest WUE but caused higher reduction in peanut and sunflower yields by $12.90 \%$ (in pod yield) and $19.25 \%$ (in seed yield), while irrigation treatment I2 (1.0 of ETo) reduced yield by $2.36 \%$ for peanut and $2.17 \%$ for sunflower, respectively, as average of both seasons compared to high water irrigation treatments 1.2 ETo. Therefore, it is recommended to irrigate peanut/sunflower intercropping pattern grown in sandy soil with an amount of 1.0 of ETo with $100 \%$ peanut $+50 \%$ sunflower under sprinkler irrigation to increase water use efficiency. Similar results were obtained by Gaballah and Ouda (2008) and Metwally et al. (2017).

\section{Water productivity under irrigation treatments.}

The results in Table (11) showed that water productivity tended to increase with the decreasing in the irrigation water applied from 1.2 to 0.8 ETo. The highest values of water productivity $(0.183$ and 0.194 CUs/mm) were obtained for the irrigation treatments 0.8 ETo with P3 $(100 \% \mathrm{P}+50 \% \mathrm{~S})$, followed by the same pattern P3 under I2 irrigation treatment (0.181 and 0.194 CUs $/ \mathrm{mm}$ ) of in first and second seasons, respectively (Table11). While, the lowest values were achieved by sole pattern of both crops under 1.2 ETo irrigation treatment. These results indicate that, the increase in water productivity under intercropping pattern is higher than sole pattern. This trend of results was obtained by Taha (2012).

\section{Land Equivalent Ratio (LER) and Aggressivity.}

The total LERs of all the intercropping treatments surpassed the unit indicating yield advantage, as compared to sole pattern of peanut or sunflower crops (Table 12). Relative yield of peanut were higher than those of sunflower in all patterns. The land use was increased by $56.9 \%$ followed by 53.0 and $41.8 \%$ for P3 pattern (50\% sunflower) under I1, I2 and I3, respectively, as average of two seasons.

Maximum LER (1.569) was obtained when peanut plants were associated with $50 \%$ of sunflower plants (P3) and irrigated with higher irrigation water (1.2 of ETo) as average of two seasons. While the lowest LER (1.189) was achieved with irrigate P1 $(100 \% \mathrm{P}+25 \% \mathrm{~S})$ under 0.8 of ETo treatment. The sufficient amount of irrigation water increased LER due to enhancement yield and its components. The results of Feng et al., 2016 and Metwally et al. (2017) are coincided with these results. 
Table 9. Effect of irrigation treatments, intercropping patterns and their interaction on water use efficiency $(\mathrm{kg} / \mathrm{mm})$ and water equivalent ratio in both seasons

\begin{tabular}{|c|c|c|c|c|c|c|c|c|c|c|c|c|c|}
\hline \multirow[b]{2}{*}{ I x P } & & \multicolumn{6}{|c|}{2016 season } & \multicolumn{6}{|c|}{2017 season } \\
\hline & & $\begin{array}{c}\mathrm{WUE}_{\mathrm{P}} \\
\mathrm{kg} / \mathrm{mm}\end{array}$ & $\underset{\mathbf{k g} / \mathbf{m m}}{\mathrm{WUE}_{\mathrm{S}}}$ & $\begin{array}{c}\text { Total } \\
\text { WUE } \\
\text { kg/mm } \\
\end{array}$ & $\begin{array}{c}\text { WER } \\
\text { Peanut }\end{array}$ & $\begin{array}{c}\text { WER } \\
\text { Sunflower }\end{array}$ & WER & $\begin{array}{c}\mathrm{WUE}_{\mathrm{P}} \\
\mathrm{kg} / \mathrm{mm}\end{array}$ & $\underset{\mathrm{kg} / \mathrm{mm}}{\mathrm{WUE}_{\mathrm{S}}}$ & $\begin{array}{c}\text { Total } \\
\text { WUE } \\
\text { kg/mm }\end{array}$ & $\begin{array}{c}\text { WER } \\
\text { Peanut }\end{array}$ & $\begin{array}{l}\text { WER } \\
\text { Sunflower }\end{array}$ & WER \\
\hline I1 & $\mathrm{P}_{1}$ & 8.08 & 2.51 & 10.59 & 0.80 & 0.30 & 1.10 & 8.11 & 2.63 & 10.74 & 0.82 & 0.30 & 1.12 \\
\hline 1.2 & $\mathrm{P}_{2}$ & 7.95 & 3.01 & 10.96 & 0.79 & 0.35 & 1.14 & 7.80 & 3.15 & 10.85 & 0.79 & 0.36 & 1.15 \\
\hline of & $\mathrm{P}_{3}$ & 7.36 & 4.09 & 11.45 & 0.73 & 0.48 & 1.21 & 7.08 & 4.10 & 11.18 & 0.72 & 0.48 & 1.20 \\
\hline \multirow[t]{2}{*}{ ETo } & $\mathrm{P}_{4}$ & 10.04 & - & 10.04 & - & - & - & 9.90 & - & 9.90 & - & - & - \\
\hline & $\mathrm{P}_{5}$ & - & 8.48 & 8.48 & - & - & - & - & 8.62 & 9.34 & - & - & - \\
\hline I2 & $\mathrm{P}_{1}$ & 9.74 & 2.91 & 12.65 & 0.85 & 0.33 & 1.18 & 9.63 & 3.10 & 12.72 & 0.85 & 0.34 & 1.19 \\
\hline 1.0 & $\mathrm{P}_{2}$ & 9.17 & 3.82 & 12.99 & 0.80 & 0.43 & 1.23 & 9.09 & 3.93 & 13.02 & 0.80 & 0.43 & 1.23 \\
\hline of & $\mathrm{P}_{3}$ & 8.44 & 4.51 & 12.94 & 0.73 & 0.51 & 1.25 & 8.41 & 4.69 & 13.10 & 0.74 & 0.52 & 1.26 \\
\hline \multirow[t]{2}{*}{ ETo } & $\mathrm{P}_{4}$ & 11.47 & - & 11.47 & - & - & - & 11.38 & - & 11.38 & - & - & - \\
\hline & $\mathrm{P}_{5}$ & - & 8.80 & 8.80 & - & - & - & - & 9.10 & 9.88 & - & - & - \\
\hline I3 & $\mathrm{P}_{1}$ & 10.35 & 2.58 & 12.93 & 0.77 & 0.26 & 1.03 & 10.40 & 2.73 & 13.13 & 0.78 & 0.27 & 1.05 \\
\hline 0.8 & $\mathrm{P}_{2}$ & 9.86 & 3.94 & 13.80 & 0.72 & 0.40 & 1.13 & 9.91 & 4.06 & 13.97 & 0.74 & 0.40 & 1.14 \\
\hline \multirow{3}{*}{$\begin{array}{l}\text { OI } \\
\text { ETo }\end{array}$} & $\mathrm{P}_{3}$ & 9.38 & 4.44 & 13.82 & 0.70 & 0.45 & 1.15 & 9.32 & 4.68 & 14.02 & 0.70 & 0.46 & 1.16 \\
\hline & $\mathrm{P}_{4}$ & 13.46 & - & 13.46 & - & - & - & 13.37 & - & 13.37 & - & - & - \\
\hline & $\mathrm{P}_{5}$ & - & 9.80 & 9.80 & - & - & - & - & 10.10 & 10.10 & - & - & - \\
\hline
\end{tabular}

Table 10. Water use efficiency for peanut/sunflower intercropping pattern under different irrigation treatments in both growing season

\begin{tabular}{|c|c|c|c|c|c|c|c|}
\hline \multirow{2}{*}{\multicolumn{2}{|c|}{$\begin{array}{l}\text { Irrigation Treat. } \\
\text { \& Inter. pattern }\end{array}$}} & \multicolumn{2}{|c|}{$\begin{array}{c}\text { Consumed irrigation } \\
\text { water, } \mathrm{Cu}(\mathrm{mm} / \mathrm{ha})\end{array}$} & \multicolumn{2}{|c|}{$\begin{array}{c}\text { Total Cereal units } \\
\text { (CUs/ha) }\end{array}$} & \multicolumn{2}{|c|}{$\begin{array}{c}\text { Water use efficiency } \\
\text { (CUs /mm) }\end{array}$} \\
\hline & & 2016 & 2017 & 2016 & 2017 & 2016 & 2017 \\
\hline \multirow{5}{*}{$\begin{array}{c}\mathrm{I} 1 \\
1.2 \text { ETo }\end{array}$} & P1 & 395 & 395 & 62.36 & 63.46 & 0.158 & 0.161 \\
\hline & $\mathrm{P} 2$ & 392 & 401 & 65.14 & 66.15 & 0.166 & 0.165 \\
\hline & P3 & 403 & 415 & 72.52 & 73.22 & 0.180 & 0.176 \\
\hline & $\mathrm{P} 4$ & 343 & 350 & 45.91 & 46.20 & 0.134 & 0.132 \\
\hline & P5 & 271 & 278 & 45.96 & 47.92 & 0.170 & 0.172 \\
\hline \multirow{5}{*}{$\begin{array}{c}\mathrm{I} 2 \\
1.0 \text { ETo. }\end{array}$} & P1 & 322 & 329 & 60.56 & 62.61 & 0.188 & 0.190 \\
\hline & $\mathrm{P} 2$ & 327 & 334 & 65.00 & 66.73 & 0.199 & 0.200 \\
\hline & P3 & 336 & 344 & 68.10 & 70.86 & 0.203 & 0.206 \\
\hline & P4 & 293 & 301 & 44.82 & 45.67 & 0.153 & 0.152 \\
\hline & P5 & 251 & 258 & 44.20 & 46.98 & 0.176 & 0.182 \\
\hline \multirow{5}{*}{$\begin{array}{c}\mathrm{I} 3 \\
0.80 \mathrm{ET} .\end{array}$} & P1 & 259 & 263 & 49.11 & 52.85 & 0.190 & 0.201 \\
\hline & $\mathrm{P} 2$ & 263 & 267 & 55.30 & 56.95 & 0.210 & 0.213 \\
\hline & P3 & 270 & 278 & 57.76 & 60.65 & 0.214 & 0.218 \\
\hline & P4 & 236 & 240 & 42.35 & 42.78 & 0.179 & 0.178 \\
\hline & P5 & 203 & 206 & 39.78 & 41.60 & 0.196 & 0.202 \\
\hline
\end{tabular}

Also, results indicated that in all intercropping combination, sunflower was the dominant intercrop component whereas peanut was the dominated in both seasons. This is indicated that sunflower had higher competitive ability compared with peanut. Similar results were obtained by El-Sawy et al. (2006), Nassar et al. (2008) and Abd El-Zaher et al. (2009).

\section{Total and net income (L.E./ha)}

Results in Table (12) indicated that increasing irrigation water applied increased total and net income, also intercropping patterns under irrigation treatments
1.2 and 1.0 of ETo gained the highest total and net income compared with sole peanut. The highest total and net income (L.E.34670 and 22589/ha) were obtained when irrigated P3 $(100 \% \mathrm{P}+50 \% \mathrm{~S})$ with sufficient water irrigation 1.2 of ETo. While the lowest total and net income under intercropping patterns (L.E. 28023 and 16463/ha) were achieve when irrigated P1 $(100 \% \mathrm{P}+25 \% \mathrm{~S})$ with 0.8 ETo treatment, as average in both seasons. These results are in harmony with ElSawy et al. (2006), Nassar et al. (2008) and Abd ElZaher et al. (2009). 
Table 11. Water productivity for peanut/sunflower intercropping pattern under different irrigation treatments in both growing season

\begin{tabular}{|c|c|c|c|c|c|c|c|}
\hline \multirow{2}{*}{\multicolumn{2}{|c|}{$\begin{array}{l}\text { Irrigation Treat. } x \\
\text { Inter. pattern }\end{array}$}} & \multicolumn{2}{|c|}{$\begin{array}{l}\text { Applied irrigation water } \\
\qquad(\mathrm{mm} / \mathrm{ha})\end{array}$} & \multicolumn{2}{|c|}{$\begin{array}{l}\text { Total Cereal units } \\
\text { (CUs/ ha) }\end{array}$} & \multicolumn{2}{|c|}{$\begin{array}{l}\text { Water productivity } \\
\text { (CUs/mm) }\end{array}$} \\
\hline & & 2016 & 2017 & 2016 & 2017 & 2016 & 2017 \\
\hline \multirow{5}{*}{$\begin{array}{c}\text { I } 1 \\
1.2 \text { of } \\
\text { ETo }\end{array}$} & $\mathrm{P} 1$ & 451 & 439 & 62.36 & 63.46 & 0.138 & 0.145 \\
\hline & $\mathrm{P} 2$ & 451 & 439 & 65.14 & 66.15 & 0.144 & 0.151 \\
\hline & P3 & 451 & 439 & 72.52 & 73.22 & 0.161 & 0.167 \\
\hline & $\mathrm{P} 4$ & 451 & 439 & 45.91 & 46.20 & 0.102 & 0.105 \\
\hline & P5 & 451 & 439 & 45.96 & 47.92 & 0.102 & 0.109 \\
\hline \multirow{5}{*}{$\begin{array}{c}\mathrm{I} 2 \\
1.0 \text { of } \\
\text { ETo }\end{array}$} & $\mathrm{P} 1$ & 376 & 366 & 60.56 & 62.61 & 0.161 & 0.171 \\
\hline & $\mathrm{P} 2$ & 376 & 366 & 65.00 & 66.73 & 0.173 & 0.182 \\
\hline & P3 & 376 & 366 & 68.10 & 70.86 & 0.181 & 0.193 \\
\hline & $\mathrm{P} 4$ & 376 & 366 & 44.82 & 45.67 & 0.119 & 0.125 \\
\hline & P5 & 376 & 366 & 44.20 & 46.98 & 0.118 & 0.128 \\
\hline \multirow{5}{*}{$\begin{array}{c}\mathrm{I} 3 \\
0.8 \text { of } \\
\text { ETo }\end{array}$} & $\mathrm{P} 1$ & 303 & 293 & 49.11 & 52.85 & 0.162 & 0.180 \\
\hline & $\mathrm{P} 2$ & 303 & 293 & 55.30 & 56.95 & 0.183 & 0.194 \\
\hline & P3 & 303 & 293 & 57.76 & 60.65 & 0.191 & 0.207 \\
\hline & $\mathrm{P} 4$ & 303 & 293 & 42.35 & 42.78 & 0.140 & 0.146 \\
\hline & P5 & 303 & 293 & 39.78 & 41.60 & 0.131 & 0.142 \\
\hline
\end{tabular}

Table 12. Effect of irrigation treatments, intercropping patterns and their interaction on land equivalent ratio (LER), aggressivity (A) and total and net income in both seasons

\begin{tabular}{|c|c|c|c|c|c|c|c|c|}
\hline \multicolumn{2}{|c|}{ I $x P$} & \multirow{2}{*}{$\begin{array}{c}\begin{array}{c}\mathbf{L} \\
\text { peanut }\end{array} \\
0.926\end{array}$} & \multirow{2}{*}{$\begin{array}{c}\text { L sunflower } \\
0.432\end{array}$} & \multirow{2}{*}{$\begin{array}{l}\text { LER } \\
1.358\end{array}$} & \multirow{2}{*}{$\begin{array}{c}\mathbf{A p} \\
-1.002\end{array}$} & \multirow{2}{*}{$\begin{array}{c}\text { As } \\
1.002\end{array}$} & \multirow{2}{*}{$\begin{array}{c}\begin{array}{c}\text { Total } \\
\text { income/L. } \\
\text { E./ha }\end{array} \\
33739\end{array}$} & \multirow{2}{*}{$\begin{array}{c}\begin{array}{c}\text { Net } \\
\text { income } \\
\text { L.E./ha }\end{array} \\
22180\end{array}$} \\
\hline & $\mathrm{P} 1$ & & & & & & & \\
\hline 11 & $\mathrm{P} 2$ & 0.904 & 0.512 & 1.415 & -0.842 & 0.842 & 33941 & 22208 \\
\hline $\begin{array}{c}1.2 \\
\text { f ET }\end{array}$ & P3 & 0.855 & 0.714 & 1.569 & -0.888 & 0.888 & 34670 & 22589 \\
\hline & $\mathrm{P} 4$ & 1 & - & 1 & & & 31224 & 20186 \\
\hline & P5 & - & 1 & 1 & & & 11183 & 4579 \\
\hline \multirow{5}{*}{$\begin{array}{c}\mathrm{I} 2 \\
1.0 \text { of } \\
\text { ETo }\end{array}$} & $\mathrm{P} 1$ & 0.929 & 0.429 & 1.358 & -0.985 & 0.985 & 33148 & 21588 \\
\hline & $\mathrm{P} 2$ & 0.890 & 0.562 & 1.452 & -1.062 & 1.062 & 33387 & 21653 \\
\hline & P3 & 0.844 & 0.687 & 1.530 & -0.822 & 0.822 & 33337 & 21256 \\
\hline & $\mathrm{P} 4$ & 1 & - & 1 & & & 30673 & 19634 \\
\hline & P5 & - & 1 & 1 & & & 10862 & 4257 \\
\hline I3 & $\mathrm{P} 1$ & 0.848 & 0.341 & 1.189 & -0.900 & 0.900 & 27785 & 16225 \\
\hline 0.8 & $\mathrm{P} 2$ & 0.820 & 0.521 & 1.341 & -1.144 & 1.144 & 28725 & 16991 \\
\hline \multirow[t]{3}{*}{ ETo } & P3 & 0.804 & 0.614 & 1.418 & -0.798 & 0.798 & 29144 & 17063 \\
\hline & $\mathrm{P} 4$ & 1 & - & 1 & & & 28856 & 17817 \\
\hline & P5 & - & 1 & 1 & & & 9694 & 3090 \\
\hline
\end{tabular}

\section{CONCLUSION}

Water equivalent ratios and land equivalent ratios of all intercropping patterns were greater than unity, which implied that higher water and land productivity can be attained under intercropping systems. Values of water use efficiency among irrigation treatments showed the superiority of intercropping because of its higher yield than that of sole crops. The highest value of water equivalent ratio (1.255) was produced with $\mathrm{P} 3$ under 1.0 ETo treatment, on average basis of both growing seasons. The maximum value of land equivalent ratio (1.569) and net income (L.E. 22589/ha) were recorded with P3 intercropping patterns irrigated with 1.2 of ETo treatment, as average of both seasons. Thus, we recommend the implementation of $\mathrm{P} 3$ intercropping system, namely $100 \%$ peanut $+50 \%$ sunflower irrigated with 1.2 of ETo to increase land productivity in sandy soil under sprinkler irrigation or with 1.0 of ETo under water security where yield lose were low. Under severe 
drought conditions, we recommended application of 0.8 ETo.

\section{REFERENCES}

A.O.A.C. 1995. Official methods of analysis of the association of official agricultural chemists, $16^{\text {th }}$ Ed. Washington, D.C. U.S.A.

Abd El-Hafez, S.A, A.A. El-Sabbagh, A.Z. El-Bably and E.I. Abou-Ahmed. 2002. Evaluation of sprinkler irrigation of sunflower in North Delta, Egypt.Alex.j.Agric.Res.47 (1):157-153, 2002.

Abd El-halim,A.K., A.M. Awad and M.E. Moursy.2016.Response of Peanut to some Kind of Organic Fertilizers under Drip and Sprinkler Irrigation by Stem. Alex. Sci. Exch. J. 37:703-713.

Abd El-Zaher, Sh.R., E.E. Mohamadain and R.A.A. Atalla. 2009. Effect of intercropping sunflower with peanut under different rates of nitrogen fertilization on yield components of both crops. Mansoura Univ. J. of Agric. Sci., 34(3): 2097 - 2114.

Abdel-Wahab, Sh.I. and A. M. El Manzlawy. 2016.Yield and quality of intercropped sunflower with soybean under different sunflower plant spacings and slow-release nitrogen fertilizer rates in sandy soil. Inter. J. of Appl. Agric. Sci., 2(3): 32-43.

Abou-Zeid, M. 2002. Egypt and World water goals, Egypt statement in the world summit for sustainable development and beyond, Johannesburg.

Adeboye O. B., B. Schultz, K. O. Adekalu and K. Prasad. 2016. Impact of water stress on radiation interception and radiation use efficiency of soybeans (Glycine max L. Merr.) in Nigeria. Braz. J. Sci. Technol., 3(15):1-21.

Agriculture Statistics. 2016. Summer and Nile Crops. Agriculture Statistics and Economic Sector, 2 ${ }^{\text {nd }}$ Ed., Ministry of Agriculture and Land Reclamation, Egypt.

Asik , F.F. and R. Yildiz. 2015. Effect of drought on peanut to yield components. $2^{\text {nd }}$ ICSAE, Inter. Conf. on Sustainable Agric. And Env., September 30- October 03, 2015, Konya, Turkey. Proceeding book, volum I, II:817-821.

Awal, M.A., H. Kosh and T. Ikeda. 2006. Radiation interception and use by maize/peanut intercrop canopy. Agric. and Forest Meteor., 13(1-2):74-83.

Bilalis, D. A, A. Karkanisa, A. Efthimiadoua, A. Konstantasa,and V. Triantafyllidis. 2009. Effects of irrigation system and green manure on yield and nicotine content of Virginia (flue-cured) Organic tobacco (Nicotianatabaccum), under Mediterranean conditions Industrial crops and products 29 (2009) 388-394.

Brockhaus, F.A. 1962. ABC der Landwirtschaft, Vol.I VEB, F.A. BrockhausVerlag, Leipzig.G.D.R. pp 790 (in German).

Casadebaig, P., P. Debaeke and J. Lecoeur. 2008. Thresholds for leaf expansion and transpiration response to soil water deficit in a range of sunflower genotypes. European Journal of Agronomy 28: 646-654.
El-Dakrourry, M.A.E. 2015. Water management under developed irrigation systems for sunflower crop in old lands. Ph.D. Thesis, Fac. of Agric., Benha Univ., Egypt.

El-Sawy, W.A., M.G. El-baz and S.E.A.Toaima. 2006. Response of two peanut varieties to intercropping with sunflower under different sunflower sowing dates. Arab J. of Nuclear Sci. and Appl., 21(3):193-210.

Fageria, N. K., V. C. Baligar and C.Jones. 1997. Growth and Mineral Nutrition of Field Crop. 2nd ed. Marcel Dakker, Inc, New York 1001 K. pp: 494.

Feng, L., Z. Sun, M. Zheng, M. Muchoki, J. Zheng, N. Yang, W. Bai, CH. Feng, Z. Zhang, Q. Cai and D. Zhang. 2016. Productivity enhancement and water use efficiency of peanut-millet intercropping. Pak. J. Bot., 48(4): 14591466.

Fereres, E.M. and A. Soriano. 2007. Deficit irrigation for reducing agricultural water use. Integrated approach to sustain and improve plant production under drought stress special issue. J. Exp. Bot., 58: 147-159.

Gaballah M. S. and S. A. Ouda. 2008. Effect of water stress on the yield of soybean and maize grown under different intercropping patterns. Twelfth Inter. Water Tech. Conf., Alexandria, Egypt (1-14).

Gholinezhad E., A. Aynaband, A. H. Ghorthapeh, G. Noormohamadi, I. Bernousi. 2009. Study of the effect of drought stress on yield, yield components and harvest index of sunflower hybrid Iroflor at different levels of nitrogen and plant population. Not. Bot. Hort. Agrobot. Cluj-Nacopa., 37 (2): 85-94.

Gomez, K.A. and A. Gomez. 1984. Statistical procedures for agricultural research. $1^{\text {st }}$ ed. John Willey \& Sons, New York.

Haro R. J., J. L.Dardanelli, M. E.Otegui and D. J.Collino. 2008. Seed yield determination of peanut crops under water deficit: Soil strength effects on pod set, the sourcesink ratio and radiation use efficiency. Field Crops Res., 109 (1-3):24-33.

Hsiao, T.C. 1973. Plant responses to water stress. Ann. Rev. Plant Physiol., 24:519-570.

Jiao, N.Y., C. Zhao, T.Y. Ning, L.T. Hou, G.Z. Fu, Z.J. Li and M.C. Chen. 2008. Effects of maize-peanut intercropping on economic yield and light response of photosynthesis. Ying Yong Sheng Tai Xue, 19 (5):981985.

Kandel , H. J., A. A. Schneiter and B. L. Johnson. 1996. Intercropping legumes into sunflower at different growth stages. Crop Sci., 37 (5): 1532-1537

Langeroodi A.R. S., B. Kamkar, J. A. Teixeira da Silva and M. Ataei. 2014. Response of sunflower cultivars to deficit irrigation. Helia, 37(60): 37-58

Lesoing, G. W. and C. A. Francis. 1999. Strip intercropping of grain sorghum/soybean in irrigated and rainfed environments. J. of Production Agric., 12 (4): 601-606.

Loomis, R.S. and D.J. Connor. 2002. Crop Ecology: Productivity and management in agricultural system. Cambridge University press. 
Majumdar D.K. 2002. Irrigation Water Management: Principles and Practice. $2^{\text {nd }}$ ed. Prentice-Hall of India, New Delhi- 110001.487p.

Mao, L.L., L.Z. Zhang, W.W. Li, W.V.D. Werf, J.H. Sun, H. Spiertz and L. Li. 2012. Yield advantage and water saving in maize/pea intercrop. Field Crops Research, 138: 11-20.

Mc-Gilichrist, C.A. 1965. Analysis and competition experiments. Biometrics, 21: 975-985.

Merrim, J.L. and J.Keller. 1978. Farm irrigation system evaluation: A guide for management. Deparment of Agriculture and irrigation Engineering, Utah Stat University, Loban, USA.

Metwally A.A., S.A. Safina, R. El-Killany and N. A. Saleh. 2017. Productivity, land equivalent ratios and water use efficiency of intercropping corn with soybean in Egyp. RJPBCS, 8(4):328-344.

Nassar, A.N.M., A.M. Abdel-Galil and H.M.Taher. 2008. Effect of intercropping systems and weed control treatments on peanut and sunflower productivity and associated weeds under sandy soil conditions. Mini J. of Agric. Res. \& Develop., 28 (4):671-700.

Nezami, A., H. R. Khazaei, Z. Boroumand Rezazadeh and A. Hosseini. 2008. Effects of drought stress and defoliation on sunflower (Helianthus annuus L.) in controlled conditions. DESERT 12 : 99-104.

NWRP. 2002. Facing the challenge. National Conference. Cairo, April 29, 2002. National water Resources plan project, planning sector, Ministry of Water Resources \& irrigation.

Pearce, R.B., R.H. Brown and R.E.Blaser. 1996. Relationship between leaf area index, light interception and net photosynthesis in orchard grass. Crop Sci., 5, 553-556.

Rowland, D. L., W. H.Fairclotha, P.Payton, . T. Tissue, J. A.Ferrelld, R.B.Sorensen and C. L.Butts. 2012. Primed acclimation of cultivated peanut (Arachis hypogaea L.) through the use of deficit irrigation timed to crop developmental periods. Agric. Water Mang. 113: 85-95.

Sankaran, V.M. and G. Kuppuswamy. 1992. Intercropping studies in peanut (Arachis hypogaea L.). J. Agron. \& Crop Sci., 168: 34-36.
Snyder R.L., M. Orang, K. Bali and S. Eching. 2004. Basic irrigation BIS'http://www.waterplan.water.ca.gov/landwateruse/wat 'eruse/Ag/CUP/Californi/Climate_Data_010804.xls.

Stanhill, G. 1986. Water use efficiency. Advances in Agronomy, 39, 53-85.

Taha A. M. 2012. Effect of climate change on maize and wheat grown under fertigation treatments in newly reclaimed soil. Ph.D. Thesis, Tanta University, Egypt.

Taha. A. M. 2013. Using CropSyst Model to Simulate the Effect of Fertigation Practices as Adaptation Strategy to Climate Change in Egypt. Lambert Academic Publishing. Germany. 233 pp.

Tan, K.H. 1996. Soil sampling, preparation and analysis. New York (NY): Marcel Dekker. Brockhaus, F. A. 1962. A B $\mathrm{C}$ der land wirtscheft B. and A-K 2 nd Edit VEB F. A. Brockhaus Verlay, Leipzg.

Vermeiren, L. and G.A. Jopling. 1984. Localized Irrigation. FAO, Irrigation and Drainage Paper no. 36, Rome, Italy.

Waller, R.A. and D.B. Duncan. 1969. Symmetric multiple comparison problem. Amer. Stat. Assoc. December, 14851503.

Willey, R.W. 1979. Intercropping: Its importance and research needs. Part1. Competition and yield advantages. Field Crop Abstr., 32:1-10.

Zhang, H. 2003. Improving water productivity through deficit irrigation: Examples from Syria, the North China Plain and Oregon, USA. In Water Productivity in Agriculture: Limits and opportunities for Improvement (Eds. J.W. Kijne, R. Barker and D. Molden), pp. Wallingford, UK, and Colombo, CABI Publishing and International Water Management Institute.

Zhang F.Y., P.T. Wu, X.N. Zhao and X.F. Cheng. 2012. Water-saving mechanisms of intercropping system in improving cropland water use efficiency. Chin. J. Appl. Ecol., 23: 1400-1406. 


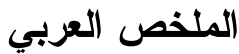

\section{تعظيم إنتاجية الأرض والمياه بتحميل دوار الشمس مع الفول السودانى تحت الرى بالرش}

أميرة عطية الميهى، أحمد محمد طه ، أحمد محمد عبداله

محصول من القرون و الزيت للهكتار مقارنة بأنماط التحميل

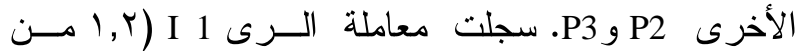

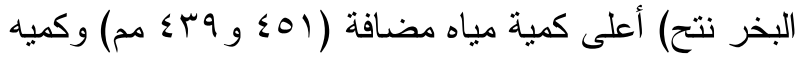

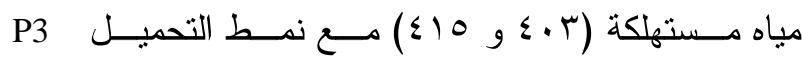

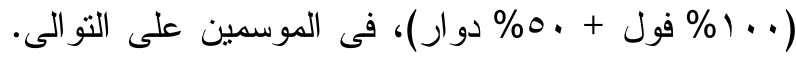

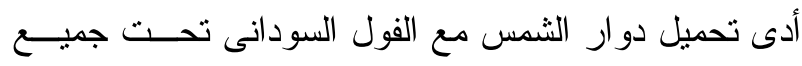
معاملات الرى المختلفة إلى زيادة كفاءة إستخدام مياه الرى

(كجم / مم أو وحدة حبوب/مم) مقارنة بالزر اعة النقيــة.

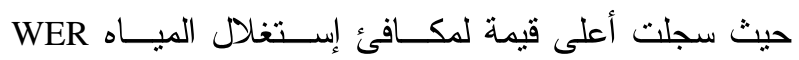

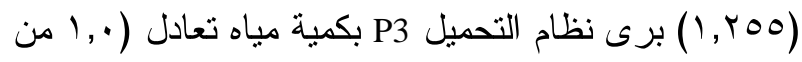
البخر نتح المرجعى) كمنوسط للموسمين. حقق نمط التحميل

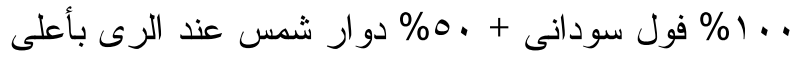

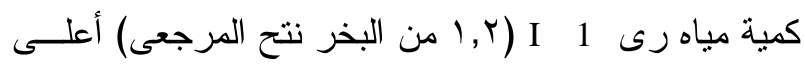

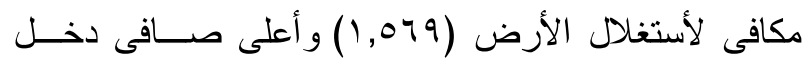

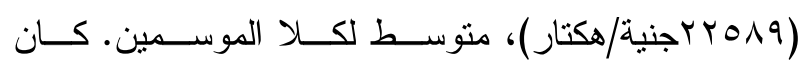

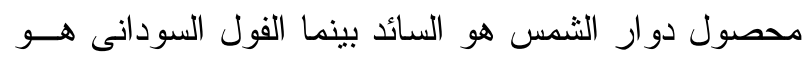

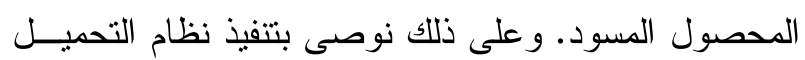

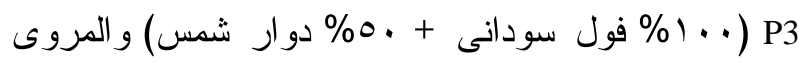
بكمية مياه تعادل r, 1, من البخر نتح المرجعى (I1) لزيادة

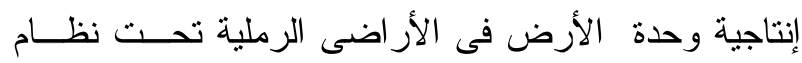

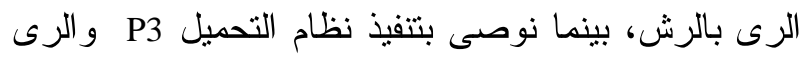

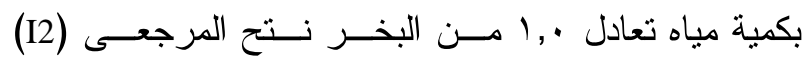

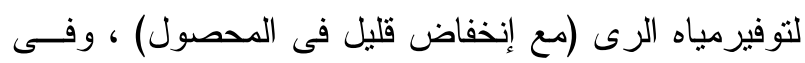

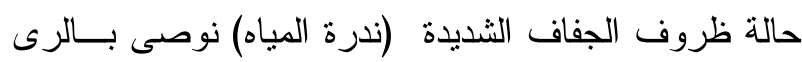
بكمية مياه تعادل ^, · من البخرنتح مرجعى.
يعتبر نمط التحميل الملائم و استخدام نظام الري عــالي

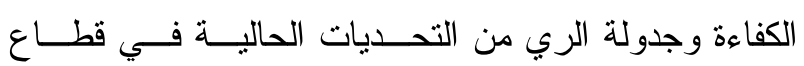

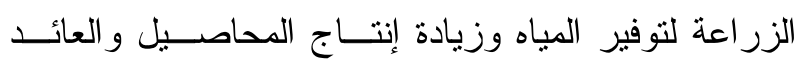

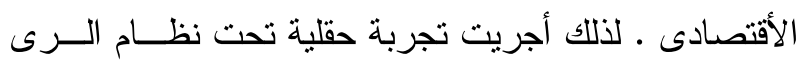

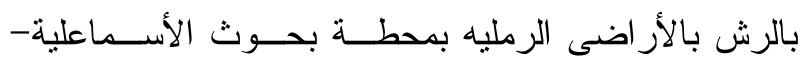

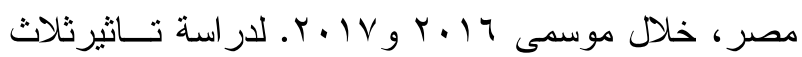
معاملات للرى على المحصول و المكافئ المائى و الأرضى لانى

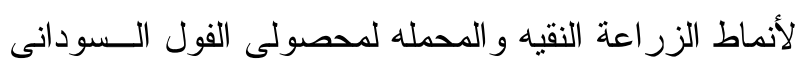

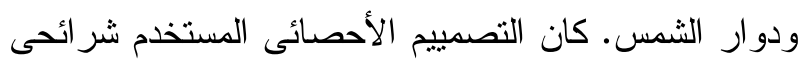
فى ثلاث مكررات. كانت معاملات الرى على النحو التالى النى

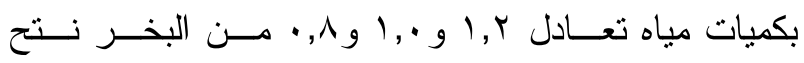

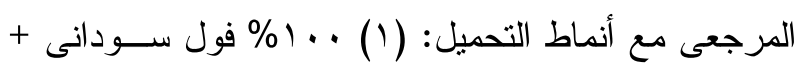

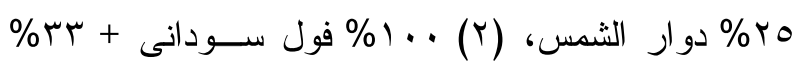

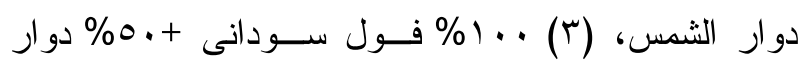

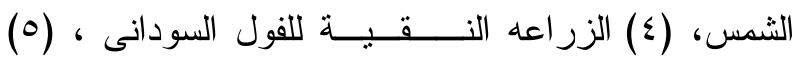

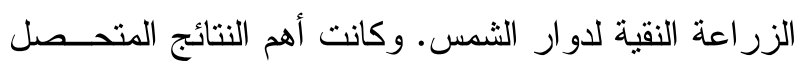

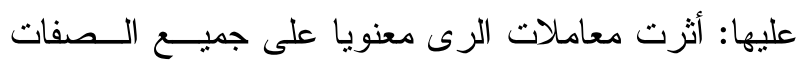
المدروسه للفول السودانى ودوار الثمس. أدى الرى بكميه

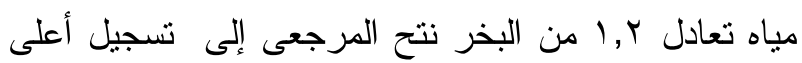

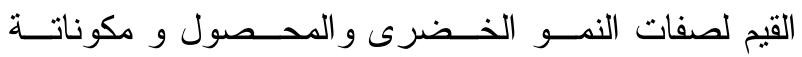
بالإضافة إلى محصول الزيت/هكتار لكلا المحصولين، مع

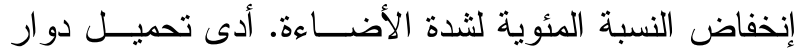

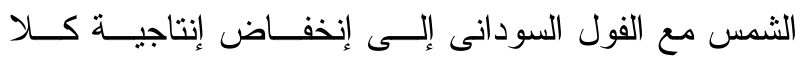

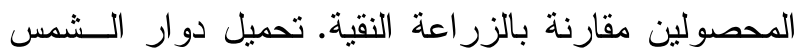

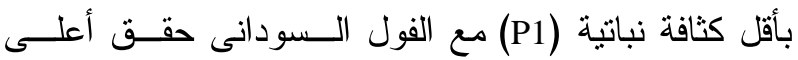

